\title{
Realismos Autoritário e Liberal: Aspectos da Imaginação sobre Representação Política em Fins do Século XIX e Princípios do XX
}

Cristina Buarque de Hollanda

Ivo Coser ${ }^{2}$

${ }^{1}$ Universidade do Estado do Rio de Janeiro (UERJ), Rio de Janeiro, RJ, Brasil. E-mail: cristinabuarque@iesp.uerj.br

${ }^{2}$ Universidade Federal do Rio de Janeiro (UFRJ), Rio de Janeiro, RJ, Brasil. E-mail: ivocoser@uol.com.br.

\section{INTRODUÇÃO}

T os tempos de democracia incerta que sucederam o Estado Novo 1 no Brasil, os campos do pensamento e da práxis da política, amalgamados ou fortemente imbricados entre si, começaram a se desembaraçar. Embora os sujeitos de decisão política não tenham evidentemente renunciado à condição de pensadores, tenderam a se distinguir dos que agora se queriam cientistas, observadores metódicos e rigorosos da cultura, da sociedade e da política. A distinção não inibia o acúmulo, e não raro o cientista e o político figuravam em um único personagem.

Na mesma altura, e em afinidade com o movimento apenas descrito, surgiram os primeiros esforços de sistematização dos saberes que compunham as recém-batizadas Ciências Sociais. Entre os pioneiros nesta seara estiveram Fernando de Azevedo ${ }^{1}$, Djacir Menezes ${ }^{2}$, Edson Carneiro, Costa Pinto ${ }^{3}$ e, o mais destacado entre eles, Florestan Fernandes ${ }^{4}$. A despeito de importantes nuances na delimitação, descrição e síntese dos objetos sob investigação, os autores em tela convergiram no escrutínio dos passos e requisitos de institucionalização das áreas da sociologia e da ciência política no país ${ }^{5}$. Estiveram, "grosso modo", interessados na distinção entre abordagens pré-científicas e científicas.

DADOS - Revista de Ciências Sociais, Rio de Janeiro, vol. 59, n-3, 2016, pp. 903 a 946. 
Em franco desacordo com esse viés classificatório, Guerreiro Ramos criticou o ideal de cientificidade como critério de valoração positiva. No seu lugar, propôs um princípio taxonômico calcado na preferência de induções sobre deduções, uma vez que teorias nascidas da observação de circunstâncias particulares seriam de extrato superior àquelas que emanam de princípios genéricos e desterritorializados. A querela com Florestan Fernandes pode ser tomada em termos mais genéricos, e não menos precisos, como embate ideológico entre o Departamento de Sociologia da Universidade de São Paulo (USP) e o Instituto Superior de Estudos Brasileiros (ISEB), instalado no Rio de Janeiro e vinculado ao Ministério da Educação e Cultura. Os objetos em disputa são as narrativas de longa duração - da Colônia à época contemporânea - para a nação e os saberes nela acumulados sobre sociedade, política e cultura.

Nas décadas subsequentes, multiplicaram-se os grandes apanhados sobre o campo do pensamento social e político brasileiro, mais recentemente dividido em dois. A despeito dos diferentes pontos de partida e vieses de seleção, é notável como o período da Primeira República-e, em especial, os pensamentos liberal e autoritário ali operados - mobiliza a imaginação social e política dos autores recenseadores. Sempre, é certo, em meio a esforços de atualização e adaptação às suas respectivas cenas contemporâneas. Além dos lastros no tempo futuro, análises emblemáticas do período enxergam nele a continuação de tendências já anunciadas no Império. A Primeira República, portanto, não raro figura como zona aberta de fronteira entre o passado (imperial), o presente (café com leite) e o futuro democrático (nos capítulos pré e pós-golpe).

Salvo o exemplo-limite de Raymundo Faoro, que enxerga presente e futuro como reiterações do tempo passado e aprisiona a história num panorama estático ${ }^{6}$, as disputas interpretativas têm justamente a ver com distintas descrições e articulações das diferentes camadas temporais. No repertório das grandes narrativas sobre a nação, Bolívar Lamounier, Werneck Vianna e Gildo Marçal Brandão são exemplos de autores que versam sobre temas, personagens, tempos e conceitos afins aos deste artigo. Atento aos arranjos de poder no país, Lamounier sugere a prevalência de uma ideologia de Estado calcada em "visão paternalista-autoritária do conflito social" e na precedência do princípio estatal sobre o mercado e a sociedade civil, concebida em bases orgânico-corporativas. No início dos anos 1990, em artigo que depois veio a compor seu clássico A Revolução Passiva, Werneck Vianna relê a 
Realismos Autoritário e Liberal: Aspectos da Imaginação sobre Representação...

clássica dualidade entre autoritários e liberais em uma outra chave: iberismo-americanismo, elegendo Tavares Bastos e Oliveira Vianna como personagens-síntese de uma e outra perspectiva.

Por fim, ao escrutinar os caminhos do pensamento social e político brasileiro, Brandão identifica dois grupos de intelectuais unidos por afinidades interpretativa e normativa sobre a nação, calcados, cada um deles, em idealismos marcadamente avessos: "orgânico" e "constitucional". Os termos tomados de empréstimo a Oliveira Vianna são reelaborados, ao longo das gerações intelectuais que se sucedem, por distintos marcadores de polaridade. Na renovação "pela esquerda" do idealismo orgânico de Visconde de Uruguai e Oliveira Vianna, atribuída a Guerreiro Ramos e Wanderley Guilherme dos Santos, a cena intelectual partida é rebatizada com os pares antitéticos hipercorreção-pragmatismo crítico e liberais doutrinários-autoritários instrumentais. No outro lado do espectro político, a perspectiva dual também se prolonga: é assim que Brandão, no ensaio apenas referido, retomaria implicitamente Tavares Bastos e Rui Barbosa ao "privilegiar a questão da forma de governo" e supor que uma agenda extensiva de rearranjos da política teria efeito propulsor sobre as ansiadas reformas sociais (Brandão, 2007:35).

Este artigo revisita justamente as linhagens "orgânica" e "constitucional" e, grosso modo, segue três passos. O primeiro deles é investigar a taxonomia de contraste presente nos autores que entendemos como personagens-chave do cânone interpretativo em vista, os já mencionados Vianna, Guerreiro e Santos. Em seguida, lançamo-nos ao escrutínio dos "objetos" do cânone com vistas a cotejar suas abordagens sobre representação política com etiquetas autoimputadas (idealismo orgânico e suas reelaborações futuras, no caso dos autoritários) e imputadas a partir de fora, isto é, por seus antagonistas intelectuais (idealismo utópico e suas reelaborações futuras, no caso dos liberais). Para tanto, trataremos de dois conjuntos de autores. A segunda seção do artigo é então dedicada ao primeiro dos conjuntos, composto pelos autoritários Alberto Torres e o próprio Oliveira Vianna, que, além de "mentor" do cânone, é seu próprio objeto. Ambos dedicam-se à reflexão sistemática sobre os cursos desejáveis da representação política, deslocados, é certo, do campo liberal. São reconhecidos por Guerreiro e Santos como positivamente identificados com sua circunstância nacional (Ramos, 1983:536-537). 
Quanto à terceira seção, é dedicada ao segundo conjunto de autores, os liberais José de Alencar, Assis Brasil e Gilberto Amado, figuras centrais para abordar o tema da representação política em fins do Império, princípios e meados da República. Para tratar deles, privilegiamos os temas do sistema proporcional, do mandato livre, dos partidos políticos e do voto secreto. Embora diversos, são estreitamente vinculados pelo imperativo das circunstâncias. Em todo o período em vista, as principais reflexões sistemáticas e de inspiração liberal sobre engenharia eleitoral e princípios de representação política são de sua autoria. Ainda que não tenham alcançado a notoriedade dos pensadores autoritários que compõem o primeiro grupo, suas obras e abordagens motivaram, por aproximação ou crítica, boa parte da imaginação futura sobre eleições e voto ${ }^{7}$. Aqui e ali, foram nominados pelos autores que assinam o cânone interpretativo sob observação. É o caso, por exemplo, da citação de Assis Brasil por Wanderley Guilherme dos Santos em seu ensaio clássico sobre liberalismo (Santos, 1978:97) e da referência de Gilberto Amado por Guerreiro Ramos (Ramos, 1983:537). De todo modo, uma vez que a referência a idealistas utópicos costuma ser genérica e pouco nominada ${ }^{8}$, propusemo-nos a escrutinar os autores que inequivocamente pautaram o debate sobre representação no período que se tem em vista.

Além de uma escolha oportuna para os propósitos deste artigo, sublinhamos o lugar marginal que esse conjunto de autores-chave do debate sobre representação política liberal ocupa no cânone que se tem em vista e também na literatura que o toma por objeto. Este é o caso do próprio Brandão, que, ao tratar do "liberalismo brasileiro, monarquista ou republicano", opera um claro viés de observação em favor da monarquia. Reconhece a posição "decisiva" da "questão da representação", mas caracteriza-a vagamente a partir do que seriam os termos de uma "defesa clássica" de Edmund Burke (Brandão, 2007:50-51). No repertório de pensadores nacionais, calcado estritamente no tema do federalismo, evoca poucas e pontuais referências diretas a Joaquim Nabuco, Alberto Salles e Tavares Bastos. As demais referências a autores reconhecidos como liberais são mediadas por intérpretes consagrados, entre eles o próprio Oliveira Vianna, crítico por excelência do "idealismo constitucional".

Ao traçar o percurso em três etapas, somos movidos pela hipótese de que os leitores consagrados que endossam e consolidam o cânone inaugurado por Vianna (isto é, Guerreiro Ramos e Oliveira Vianna) 
prolongam, com importantes nuances, o contraste utopia-realismo. Com o intuito de matizar a perspectiva dicotômica - que acaba por imputar simplificações analíticas a ambas as partes, sobretudo aos liberais - propomos duas importantes zonas de aproximação entre os autores em tela. A primeira delas consiste num encontro de narrativas sobre o estado da arte da sociedade brasileira: clânica, parental, alheia a estruturas de classe e marcada pela oposição entre civilização e sertão. Quanto à segunda afinidade, prescritiva, gravita em torno de dois eixos: 1) o princípio de interesse nacional, fundamento potencial de um novo tempo social e político, com contornos sociais e políticos mais nítidos e; 2) a expectativa de ação criadora do Estado, por meio da representação política, como o principal operador da transformação social.

A partir deste pano de fundo comum propomos que a abordagem de liberais como José de Alencar, Assis Brasil e Gilberto Amado possa escapar à premissa do liberalismo necessariamente utópico, alheio a considerações de circunstância. Para transformar a forma clânica e parental da sociedade brasileira, aceita por eles como condição de partida, os autores supõem a oportunidade dos instrumentos da representação liberal, passíveis de adaptação ao meio. Embora a sociedade brasileira seja origem e destino - e, portanto, fundamento de legitimidade - do processo representativo, sua direção é obra dos representantes, desde que investidos de um mandato livre e isento de amarras do localismo político. Há na forma liberal em questão um duplo movimento que nos parece escapar aos mentores do cânone: o processo representativo a um tempo desqualifica e qualifica sua origem. Isto é, confere ao representante um papel criador do povo ao mesmo tempo que reconhece os diferentes sujeitos reais ou virtuais de opiniões e interesses como agentes do interesse nacional.

Há neste aspecto importante aproximação com Alberto Torres e Oliveira Vianna. No argumento deste autor, também há protagonismo do Estado e do interesse nacional como meio e finalidade da política, respectivamente, mas o problema da representação política é equacionado de maneira distinta. E aqui reside a distância substantiva em relação aos liberais: para Torres e Vianna, o conflito político que emerge nos processos de representação liberal é em si mesmo negativo, calcado na disputa de grupos clânicos por cargos e benesses. O desenho institucional que propõem diverge, portanto, daquele dos liberais, com precedência 
do Poder Executivo em relação ao Legislativo, concebido como corpo consultivo e técnico, esvaziado de conflito.

Sem abolir o sentido de contraste entre os dois conjuntos de autores que supomos expressivos da dualidade reportada pelo cânone, sugerimos o exagero da acusação utópica ${ }^{9}$ (reelaborada como hipercorreção e doutrinarismo). Reconhecemos, é certo, seu fino ajuste à disputa política de seu contexto originário - a insatisfação de autoritários com os primeiros passos da prática republicana-liberal no país. E, depois, sua inequívoca adaptação a épocas de forte polarização da cena política nacional (os anos da ditadura militar e também aqueles que o antecederam e sucederam), quando o diagnóstico primeiro foi relido e reapropriado. Acompanhamos Santos quando afirma que as questões enfrentadas pelo ISEB às vésperas do golpe militar não traziam novidade significativa em relação àquelas que antes ocuparam o pensamento político nos anos 1930 (Santos, 1978). Além das questões substantivas, também o "estilo dicotômico", nos termos de Santos, está cá e lá.

Deslocados, contudo, das cenas políticas fortemente polarizadas, parece-nos oportuno que uma nova leitura dos objetos do cânone em vista matize - sem refutar, é certo - o sentido de contraste entre eles, atentando para as importantes linhas de continuação entre os argumentos liberal e autoritário. A despeito dos desacordos relevantes entre os grupos, identificamos afinidade substantiva em torno de diagnósticos de realidade e expectativas de ação criativa do Estado. A distinção fundamental entre os dois parece-nos sobretudo referida às diferentes visões sobre a habilitação dos homens comuns ao processo político (sobre a natureza da representação política, portanto), com impacto na definição de importância relativa dos poderes Legislativo e Executivo.

\section{UTOPIA, REALIDADE E INTERESSE: ELEMENTOS DE UM CÂNONE INTERPRETATIVO DO PENSAMENTO POLÍTICO BRASILEIRO}

No debate sobre a formação dos campos político e intelectual brasileiro, os diferentes modos de recepção de ideias e instituições do mundo moderno compuseram um importante cânone interpretativo que distingue famílias intelectuais segundo sua maior ou menor sensibilidade para lidar com temas e questões especificamente nacionais. Nesta seção, tomamos personagens de três diferentes gerações intelectuais, Oliveira Vianna, Guerreiro Ramos e Wanderley Guilherme dos Santos, 
como autores-matrizes de uma taxonomia de contraste, pautada no juízo sobre vocações nacionais. Ao tratar deles, acompanhamos Brandão na suposição de que "nenhuma grande constelação de ideias pode ser compreendida sem levar em conta os problemas históricos aos quais tenta dar respostas", embora nenhuma ideia possa ser "inteiramente resolvida em seu contexto" (Brandão, 2007:33). Ao debruçarem-se sobre o passado, os autores em vista o fazem a partir de suas lentes contemporâneas, o que resulta em nuances ou mesmo saltos analíticos entre eles. A despeito disso, não divergem da percepção de utopismo e realismo como duas ordens de motivação intelectual que correm em paralelo, essencialmente distintas entre si.

No programa político de Oliveira Vianna, a elaboração sobre duas vocações intelectuais contrapostas pela filiação ou não a modos de reflexão autênticos - isto é, nacionais - foi articulado de modo consistente, sem oscilações ou incerteza. O esforço analítico empreendido desde Populações Meridionais, em 1920, e da primeira edição de O Idealismo na Constituição, em 1927, recebeu formulação definitiva na segunda edição na mesma obra, em 1939, quando o autor propôs a distinção entre as duas formas de idealismo: orgânico e utópico.

Para Vianna, o idealismo utópico "não leva em conta os dados da experiência", ao passo que o idealismo orgânico é aquele "que se forma de realidade, que só se apoia na experiência, que só se orienta pela observação do povo e do meio" (Vianna, 1939:13). Não há mal, portanto, no princípio idealista em si. Admite suas necessidade e fecundidade potenciais: a elaboração das instituições não poderia, afinal, derivar da simples emanação dos costumes disponíveis na sociedade. O curso espontâneo das vidas social e política estaria fadado à reprodução dos vícios já verificados na incipiente experiência nacional. No Brasil e na Ibero-América em geral, a formação histórica e o meio social teriam feito nascer uma elite e um povo marcadamente avessos a práticas de impessoalidade e objetivos de grandeza nacional ${ }^{10}$. Contra a reprodução indefinida deste estado de coisas, o autor concebe a possibilidade de um idealismo oportuno, cujos operadores estariam autorizados a imaginar instituições que pudessem reformar a condição amorfa da sociedade e fundar em novos termos seu trato com a vida pública. Em termos mais específicos, somente um Estado forte seria capaz de desempenhar as funções de tutela e agregação. A diferença entre os modos de idealismo não estaria, portanto, no uso da imaginação sociall $^{11}$, mas no programa político postulado. 
Segundo Vianna, uma das características distintivas dos idealistas orgânicos em relação aos utópicos seria a atenção à "evolução orgânica da sociedade" e a produção de "visões antecipadas de uma evolução futura" (Vianna, 1939:11). Trata-se, portanto, alegadamente, de um modo realista de elaboração das ideias, pautado em observação acurada da formação histórica e social do povo e, por consequência, em imaginação plausível do vir a ser. A sintonia com a "evolução futura" exibe um sentido teleológico da história, fixado no ideal de modernidade, que fornece o conteúdo para a ação. Para alcançar a condição moderna, o programa político dos idealistas orgânicos - entre os quais se inclui o próprio Oliveira Vianna - inclui a centralização administrativa, a primazia dos direitos civis sobre os políticos, a solidariedade social, a precedência do interesse nacional sobre os interesses particulares e do Poder Executivo sobre o Legislativo ${ }^{12}$. Ao escrutinar a história política nacional, Vianna identifica apenas duas gerações de políticos comprometidos com ideias orgânicas ou plausíveis: "o pequeníssimo núcleo" que efetuou a reação conservadora no Império e os autores da Carta Constitucional de 1937 (Vianna, 1939:9 e 156).

Na genealogia crítica de Vianna, o idealismo utópico praticado por liberais brasileiros comporia um fenômeno ampliado, característico dos países latino-americanos em geral (1987a, vol. II:18). Os personagens exemplares da imaginação republicana sem relação orgânica com a sociedade nacional seriam Tavares Bastos, Rui Barbosa, Teófilo Ottoni e os constituintes de 1889 (Vianna, 1987c:22 e 1924). Pautados pela admiração das culturas europeia e estadunidense, estes homens de elite seriam operadores do divórcio entre direito lei e direito costume (Vianna, 1939, 1974, 1987c). Seus programas políticos tenderiam a convergir em torno de postulados avessos à sensibilidade orgânica de conservadores do Império e constituintes de 1937, quais sejam: a autonomia de municípios e estados, o modelo federativo, a ênfase nos partidos e nas eleições como métodos de seleção dos governantes, a proteção da liberdade e dos direitos individuais, o padrão anglo-saxão de justiça eletiva e, por fim, o protagonismo do Poder Legislativo (Vianna, 1987c, II:20). Os resultados viciosos deste programa seriam, para Vianna: o predomínio político de grupos clânicos, os conflitos intraelites, a desorganização das classes e a insolidariedade entre as mesmas.

O diagnóstico de polaridades de Vianna ganhou vida longa no campo do pensamento político brasileiro e, a despeito de acréscimos e ajustes que introduziram importantes alterações de sentido, lançou linhas pe- 
renes de interpretação sobre o fazer intelectual e político brasileiro. Os trabalhos de Guerreiro Ramos sobre a produção intelectual brasileira reeditam ao mesmo tempo que atribuem novos sentidos ao par conceitual de Vianna.

Desde seus primeiros trabalhos publicados na Revista do Serviço Social, em 1954, até a conferência intitulada A Inteligência Brasileira na Década de 1930 à Luz da Perspectiva de 1980, publicada em 1983, dois anos antes do seu falecimento, o tema do pensamento político e social brasileiro esteve no centro das reflexões do autor, sempre organizadas em torno de juízos sobre a autenticidade ou não dos enunciados e prospecções sobre o caso brasileiro ${ }^{13}$. Guerreiro aderiu ao sentido da dicotomia orgânicos-utópicos de Vianna para descrever a cena intelectual brasileira. Entre os orgânicos, rebatizados como realistas ou pragmáticos críticos, atribuiu papel fundador a Paulino José Soares de Souza, sensível aos "inconvenientes do formalismo" e à necessidade de dotar o país "de instituições fundamentais que permitissem aos governantes o máximo possível de realismo em sua ação sobre o meio social" (Ramos, 1966:347). Também afeitos à vocação realista seriam Silvio Romero, Alberto Torres e o próprio Oliveira Vianna. Apesar das distâncias de argumento, partilhariam uma postura crítica assimilativa em relação a ideias exógenas, originais do mundo moderno, buscando fortalecer o Estado-nação como ator principal de construção nacional ${ }^{14}$.

Outro elemento de identidade entre críticos assimilativos seria sua inclinação autoritária. Segundo Guerreiro, "todos esses críticos do formalismo são, em política, adeptos de regimes autoritários, repudiam o liberalismo como ineficaz no nosso caso, e aconselham a atribuição das funções dirigentes aos mais esclarecidos" (Ramos, 1966:353). Embora sensíveis "ao imperativo da construção nacional" (ibidem:360), seus modelos prospectivos parecem insuficientes: "os corretivos que propuseram foram de natureza essencialmente política e educacional e secundariamente econômica" (ibidem:421) ${ }^{15}$. Sua vocação nacional e realista, uma espécie de valor supremo para Guerreiro, amortece a possível crítica à inspiração autoritária. Para ele, a insuficiência do modelo poderá ser corrigida pelo processo de desenvolvimento industrial em curso e pela consequente formação de um sistema produtivo voltado para o mercado interno (ibidem:360).

Guerreiro não hesita em reconhecer superioridade científica dos operadores da crítica assimilativa relativamente àqueles que, "em face dos 
produtos culturais estrangeiros", assumiam "atitude dogmáticodedutiva, ou seja, aceitação literal dos mesmos, desadvertidos das contingências consuetudinárias do país" (Ramos, 1954:85). Grosso modo, o grupo de intelectuais com vocação oposta ao realismo seria exemplarmente composto por Torres Homem, Tavares Bastos e Rui Barbosa. De volta às categorias de Vianna e à comparação entre os grupos, para Guerreiro, a superioridade pragmática dos "idealistas orgânicos" em relação aos "idealistas utópicos era efetiva, malgré a inobjetividade de teoria do processo". Sua razão prática era orientada pelo "ponto de vista das exigências episódicas e momentâneas do processo" (Ramos, 1966:361). A expectativa de Guerreiro era de que a consolidação da cena moderna suprimisse a necessidade de desvio autoritário dos assimilativos críticos.

De volta aos "utópicos", Guerreiro acolhe, em parte, a classificação de Vianna, mas introduz nela importante novidade interpretativa, deslocando-a do campo estrito das ideias para o das motivações sociológicas. Para ele, o alheamento desses políticos em relação às circunstâncias sociais e políticas específicas do país seria uma condição intelectual derivada da motivação principal de suas intervenções na cena pública: "suas carreiras políticas", uma variável "realista", portanto, "quanto às reivindicações de grupos e facções que representavam" (Ramos, 1966:60). Como observa Brandão, o lastro da dicotomia de Vianna em Guerreiro não nasce de um "desejo de imitação das elites", mas da "dependência do país em relação às potências industriais do Ocidente". Uma concessão à "realidade inescapável", portanto; um "caminhar do teórico para o consuetudinário". À luz de sua crítica estrita aos idealismos esvaziados de realidade, era de se esperar, afirma Brandão, que essa atitude fosse lida na chave de virtude contextualista ou "ferramenta legítima", avessa às "veleidades ideológicas" que tanto o exasperam (Brandão, 2007:149). Não são esses, contudo, os caminhos da avaliação de Guerreiro, que afinal fazem dos "utópicos" objetos de forte crítica e condenação, o que parece "curioso" a Brandão.

A análise de Guerreiro situa os "adeptos da transplantação" no mundo estrito (e moralmente falho) dos interesses, para lançar mão de seu próprio vocabulário político. À época do Império, por exemplo, os liberais utópicos, vinculados aos interesses das oligarquias dominantes nas províncias, teriam favorecido instituições descentralizadoras (ibidem:347), crítica possivelmente extensiva a federalistas da Primeira República. À diferença dos "críticos assimilativos" ou "antiformalis- 
Realismos Autoritário e Liberal: Aspectos da Imaginação sobre Representação...

tas" - que correspondem aos "orgânicos" de Vianna - eles teriam vínculos com interesses de grupos específicos na sociedade e, portanto, ligações mais orgânicas com a cena social. Haveria realismo na utopia, portanto. Por oposição, críticos assimilativos figuram num lugar desinteressado, animados estritamente por suas teses e modelos antiformalistas ${ }^{16}$.

A partir de diferentes lugares de fala e pensamento, os dois grupos postulavam distintos modelos de superação da dualidade entre moderno e atraso. Segundo Ramos:

a interpretação post factum do idealismo utópico dos adeptos da transplantação e o "idealismo orgânico" ou "realismo" dos antiformalistas, permitida pelo processo histórico-social do país na fase contemporânea é a de que uns e outros perfilhavam estratégias opostas (1966:360).

Parece-nos que a chave de entendimento do "curioso" manifesta por Brandão é o viés nacionalista do argumento de Guerreiro, lente suprema de seu juízo sobre eventos e personagens da história nacional. Em apanhado sobre o pensamento autoritário no Brasil, Lamounier apresenta a obra de Guerreiro Ramos a partir justamente do que seria seu viés de observação sociológica: o historicismo-nacionalista. Neste modelo, as ideias políticas são narradas como sucessão de momentos imperfeitos em direção ao conhecimento científico da realidade brasileira. Tudo que acontece é validado quando antecipa a mirada nacionalista e desqualificado quando não a toma por obsessão. Haveria, segundo a crítica de Lamounier, um lastro positivista na suposição de objetividade do real e dos processos de desenvolvimento nacional. A ciência sociológica, indutiva, seria alçada a um lugar indiscutível (Lamounier, 1985).

O sentido de contraste no modelo interpretativo de Guerreiro obedece a um importante deslocamento em relação à chave real-utópico, de Oliveira Vianna: o contraponto fundamental passa a ser entre nacionais e "alienados" (Ramos, 1981:54) ${ }^{17}$. A aproximação de sentidos entre real e nacional, de um lado, e utopia e "alienação", de outro, confere novas nuances à polaridade de Vianna. Embora o tema das motivações individuais introduzido por Guerreiro abale a unidade construída por Vianna em torno da matriz utópica - uma vez que acusa realismo na utopia -, o sistema dual não cai por terra se mantemos o foco de observação nas instituições, que são a principal preocupação de Vianna. Ao propor a síntese formalismo versus antiformalismo, Guerreiro não sub- 
verte os pares de contraste de Vianna, mas atribui a eles novo arranjo de sentidos e intensidades. Em última instância, o processo histórico para Guerreiro possuiria um telos que poderia ser apanhado de maneira inequívoca: o desenvolvimento nacional preconizado pelos críticos assimilativos a despeito das suas limitações na condução deste processo. Este seria o critério fundamental para a análise das famílias intelectuais.

O terceiro autor que compõe a caracterização do cânone interpretativo sob investigação, Wanderley Guilherme dos Santos, inicia pesquisa sistemática sobre o pensamento político brasileiro em tempo de marcada polarização política: as vésperas do golpe militar. Lançou-se ao tema a pedido de Álvaro Vieira Pinto, então diretor do ISEB, a que se filiava como pesquisador ${ }^{18}$. Em um dos artigos que resultou desta agenda de pesquisa, intitulado "Raízes da Imaginação Política Brasileira", Santos observa um "estilo dicotômico" de reflexão sobre a experiência nacional que remonta a fins do século XIX e início do XX. Euclides da Cunha e a narrativa dos dois Brasis figuram como marcadores iniciais e exemplares desta perspectiva que se fixa na cena intelectual como "indiscutível", adormecida pelo Estado Novo, e "revitalizada" em meados dos anos 1950. Naquela altura, as grandes questões nacionais evocadas em 1930 foram recuperadas sob nova roupagem, mas sempre no ângulo das polaridades, tendo em seguida alcançado a época contemporânea "nas formas de uma elucubração irrealista inflexível, de um lado, e uma racionalização de um ideal ético, de outro" (Santos, 1970:155). A temporalidade em questão era o ano de 1970.

Santos acompanha o estilo dicotômico que diagnostica como moeda corrente no meio da "imaginação político-social brasileira" e divide as famílias intelectuais em duas: liberais doutrinários e autoritários instrumentais. A despeito de importantes distinções em relação a Vianna e Guerreiro, que serão logo abordadas, reedita os sentidos de utopia e realidade que lhes são caros. Para tratar do liberalismo, elenca um repertório de vícios: "fetichismo institucional", afeição a "versões cada vez mais abstratas e sofisticadas do Estado liberal", "minimização da análise histórica" e das "circunstâncias sociais" e "crença de que as boas instituições garantem a qualidade moral do sistema" (Santos, 1978:51, 97). Desde o século XIX, com o fascínio americanista de Tavares Bastos até as primeiras décadas da República, com Assis Brasil e Rui Barbosa, "os mais notáveis exemplos de liberalismo doutrinário", teria florescido o liberalismo de metas e meios. 
Realismos Autoritário e Liberal: Aspectos da Imaginação sobre Representação...

Quanto ao outro polo do espectro imaginativo, seria composto por autoritários instrumentais, entre outros ${ }^{19}$. Ao propor essa nova categoria, Santos inaugura uma tradição interpretativa sobre a linhagem autoritária de fins do Império e primeiras décadas da República ${ }^{20}$. A partir de passagens da obra de Vianna, dá relevo (ou, na leitura de seus críticos, distorce ou exagera ${ }^{21}$ ) ao que seria um aspecto essencial da sua ideia política: a condição transitória do recurso autoritário, instrumental em relação à imaginação de um futuro liberal - este, sim, liberal de fato, harmonizado com o ambiente social.

Em polêmica com Santos, Lamounier questiona a premissa do autoritarismo de meios. Afirma ser um campo autoritário essencialmente distinto do liberal, sem mediações. Para ele, os autores investigados por Santos - situados no horizonte de sentidos de Vianna - evocam o autoritarismo como finalidade em si. A forma autoritária não conteria os princípios para sua dissolução futura. Ela estaria fixada num sistema ideológico voltado para a legitimação do Estado como personagem tutelar da sociedade. Como já mencionado na introdução deste artigo, o ambiente de ideias e aspirações políticas nas últimas décadas do século XIX e primeiras do XX estaria, para Lamounier, calcado numa ideologia de Estado. Contra o princípio de mercado, pauta-se numa visão orgânico-corporativa da sociedade, numa perspectiva autoritária de conflito social, numa expectativa de sociedade civil sem sinais de vida espontânea e, por fim, numa elite voluntarista na qual se apoia um Leviatã benevolente - isto é, uma força vital de uma sociedade benevolente, cordial e cooperativa, mas incapaz de movimento próprio ${ }^{22}$.

A réplica de Santos acusa uma "confusa noção de ideologia de Esta$\mathrm{do}^{\prime 23}$ e avança em debate epistemológico ${ }^{24}$. Para os propósitos deste artigo, a polêmica importa porque reforça o argumento de aproximação do autoritarismo com valores liberais, que introduz interessante complexidade no dualismo estrito com os autoritários. Para Santos, os autoritários instrumentais teriam assimilado corretamente o sentido de construção da ordem burguesa europeia. Isto é, compreenderam que as revoluções burguesas não ocorrem quando o tecido social, impregnado do ethos burguês, subverte as instituições estatais. Ao contrário, elas requerem um longo processo em que as instituições estatais desempenham, a um só tempo, os papeis de pai e filho da nova ordem. $\mathrm{Na}$ esteira de Karl Polany, a intervenção estatal seria a base de criação da ordem de mercado (Santos, 1978:109). 
No repertório de autoritários mobilizados por Santos está Paulino José Soares de Souza, pensador que teria tido o mérito de perceber que a condição para uma ordem privada burguesa no Brasil seria a expansão do aparelho administrativo do Estado de modo subordinado a um comando único (ibidem:50). Nos anos 1930, políticos com vocação autoritária ou realista teriam dado continuidade à implantação desse programa e do respectivo ethos burguês. O objetivo último do autoritarismo da época seria, portanto, a "sociedade de mercado, reino do privatismo burguês e do individualismo". A expansão da "capacidade regulatória e simbólica do poder público" visava "financiar a expansão do Brasil burguês moderno" (ibidem:51). Na família intelectual autoritária, Oliveira Vianna teria percebido com clareza o dilema do liberalismo brasileiro: "seria necessário um sistema político autoritário para que se pudesse construir uma sociedade liberal" (ibidem:93).

Embora Santos acolha, no seu modelo compreensivo, vigoroso sentido de contraste entre utopia (reelaborada como doutrinarismo liberal) e realismo (situado estritamente na órbita de sensibilidades dos autoritários), a premissa do autoritarismo instrumental introduz importante fissura no "estilo dicotômico", que, como vimos, alcançou feições muito rígidas em Vianna e Guerreiro. No trio que compõe o cânone sob interpretação, Santos foi o que operou o dualismo em bases menos estritas, admitindo, em fase mais adiantada de sua biografia, interesse na obra de um liberal em moldes clássicos, José de Alencar. Em estudo que prefacia edição fac-similar da obra de Alencar, Santos aponta nela importante novidade, mesmo quando comparada a clássicos da teoria política do século XIX. A reflexão de Alencar seria original e sólida, recebendo a designação de teoria política, termo que o aproxima da elaboração mais refinada de autores como Stuart Mill, Tocqueville. Longe de enunciar apenas um pensamento datado e refém de circunstâncias específicas, sua contribuição interpelaria as teorias democráticas, tendo alcançado "inclusive uma solução para o enigma democrático fundamental" (Santos, 1991:50). Santos e também Tavares (1988) atribuem à reflexão política brasileira um caráter de originalidade frente aos esforços teóricos coevos. Na perspectiva deles, a originalidade não decorre da situação de marginalidade frente ao centro capitalista, mas de uma interpelação realizada nos próprios termos do debate realizado nos centros modernos ${ }^{25}$. Embora a consideração de Alencar sobre o tema da representação proporcional passe ao largo da atenção ao meio social e à formação histórica brasileira, aspectos da reflexão tipicamen- 
Realismos Autoritário e Liberal: Aspectos da Imaginação sobre Representação...

te realista, sua "desatenção utópica" não afeta sua originalidade e relevância. A leitura de Santos sobre Alencar será uma importante via de acesso a este autor.

A restrição a Alencar é justamente aquilo que o vincula a Guerreiro, a quem não poupa, contudo, crítica contundente. Reconhece no pensador isebiano a virtude de introduzir na avaliação das obras do pensamento político brasileiro os critérios de indução e dedução, em substituição ao viés formalista-institucional de Florestan Fernandes. Trata-se de uma virada interpretativa operada em estreita afinidade com seu corte nacionalista, "incomparavelmente mais fecunda" do que a que existia até então. A despeito do mérito de saída, a que correspondem potencialidades não desenvolvidas, Guerreiro teria errado ao operar com a chave autêntico-inautêntico (superposta ao par pragmatismo crítico-hipercorreção) e descartar como "irracional ou aleatória" toda produção intelectual legada à etiqueta de sociologia colonial (por oposição à de sociologia nacional) (Santos, 1967). Como seria possível sustentar a tese da alienação se o país foi capaz de "resolver" suas "questões decisivas" (entre elas, a escravidão)? (Santos, 1966). Chega-se ao que seria o paradoxo de Guerreiro (expressão nossa): "empirista radical" e propagador de um

raciocínio que deduz todas as categorias do pensamento a partir do movimento dos próprios conceitos e categorias. (...) Um raciocínio que segue uma marcha tipicamente hegeliana, que ignora a empiria, e que possivelmente chocar-se-á com o suceder real dos acontecimen$\operatorname{tos}^{26}$ (Santos, 1966:88).

A despeito das distinções entre um e outro, as clivagens propostas por Santos e também por Guerreiro introduzem no repertório de opostos de Vianna uma especulação sobre fins. Sem comprometer o contraste fundamental entre utopia e realidade, a especulação sobre finalidade ganha, nos dois autores, duas diferentes direções. Ao mover sua fúria crítica para os liberais, Guerreiro acusa neles modos utópicos para fins políticos e realistas para fins próprios. Em outras palavras, denuncia uma utopia a serviço de interesses imediatos, particulares, num contraste estrito com o caráter desinteressado de críticos assimilativos, muito afins ao significado que Vianna empresta ao idealismo orgânico. Quanto a Santos, para tratar dos autoritários, cogita sobre fins políticos que extrapolam sua agenda imediata de reformas. 


\section{ALBERTO TORRES, OLIVEIRA VIANNA E O AUTORITARISMO ORGÂNICO}

Em fins do século XIX e princípios do XX, Alberto Torres foi notável propugnador da imaginação autoritária, não raro ofuscado pela referência a Oliveira Vianna, seu discípulo confesso. Suas linhas de reflexão sobre a questão nacional foram sempre bastante aproximadas. Nas leituras de Guerreiro Ramos e Wanderley Guilherme dos Santos sobre os dois pensadores, a ênfase recai sobre dois aspectos: a particularidade da experiência nacional, inapreensível por esquemas universais e abstratos de pensamento, e a visão pragmática sobre o papel do Estado na construção de uma sociedade moderna. Ambos teriam percebido que a cada país cabem caminhos próprios na construção de uma sociedade moderna e que a organização das classes subalternas do mundo urbano não resultaria da livre disputa de interesses na sociedade, mas da ação política e diretiva da razão de Estado, operada por homens capazes de distinguir interesses particulares e imediatos do interesse bem compreendido. O pragmatismo institucional seria, portanto, obra de uma elite política alheia aos particularismos societais.

Esta abordagem põe em destaque a crítica dos autoritários à inadequação das instituições liberais à sociedade brasileira. Entretanto, deixa em segundo plano um aspecto-chave do repertório autoritário em vista: a crítica ao modelo de representação política calcado no conflito. E aqui chegamos a um ponto-chave do nosso argumento: é sobre ele, o conflito, e não sobre a sensibilidade ou não à realidade sociológica, que julgamos oportuno fundar o contraste entre autoritários e liberais ${ }^{27}$.

Para tanto, partiremos da crítica de Torres à aplicação do liberalismo a sociedades modernas em geral, e não apenas àquelas que aspiram a modernidade por meios artificiais, como o Brasil. Para ele, o espírito liberal seria portador de uma "visão revolucionária" e ao mesmo tempo simplista, fundada na premissa de oposição entre Estado e indivíduo. Desta desconfiança recíproca resultaria "uma multidão de corpos, associações, agregados ou permanentes ou adventícios" que converteriam o Estado contemporâneo na representação de um conjunto de interesses vencedores na luta política (Torres, 1982:137-138). Nos Estados contemporâneos, novos ou estabelecidos, os governantes decidiriam tendo em vista "os interesses próprios, os da classe a que pertencem, os dos amigos, os impulsos do partido, da família, da circunscrição, local ou eleitoral, das paixões ou os interesses ocasionais ou parciais, favoráveis ao poder e à ambição pessoal" (idem). Nesse 
ambiente, a democracia e a política engendrada por ela - fundada no conflito de interesses - teriam reduzido e desmoralizado o Estado, que deixa de ser o portador de um interesse mais amplo do que aquele de um partido ou de uma classe. Nas sociedades liberais, indivíduos autointeressados disputam o Estado com o objetivo de garantir benefício próprio.

A solução seria encontrar um ponto arquimediano entre os interesses, abandonando a disputa do poder a partir de visões e interesses particulares. Para Torres, "a arte de governar tem de abandonar forçosamente o critério político, em suas classificações, para adotar o critério social e econômico", que traduziria "a lei vital da sociedade" (1982:139). Nesta perspectiva, a política deveria ser orgânica, isto é, "uma política de conjunto, de harmonia, de equilíbrio" (ibidem:158). Os critérios políticos deveriam dar lugar a critérios sociais e econômicos e, assim, favorecer o interesse nacional sem as disputas de interesse que caracterizam as instituições liberais representativas ${ }^{28}$.

Na política criada a partir da democracia, a recusa do conflito não implica em recusa do povo como ator político. Alberto Torres não expressa demofobia, mas mostra-se refratário à política movida por choques de posição. O lamento sociológico dirigido à realidade nacional não tem os extratos populares - atravessados pela marca do insolidarismo - como objeto principal, mas sobretudo as elites, alheias à sua missão diretiva nacional e afeitas a estreitos interesses de classe (Kuntz, 2002:268).

O encontro de Oliveira Vianna com as ideias de Alberto Torres foi decisivo na sua formação política ${ }^{29}$. Interessante notar que, de início, ambos aderiram aos principais tópicos do programa republicano brasileiro: o federalismo, o fortalecimento dos partidos, o estímulo aos interesses particulares e a admiração pelo mundo anglo-saxão $0^{30} . \mathrm{Na}$ obra de Vianna, a visão sobre o conflito não é a princípio negativa. $\mathrm{Na}$ Inglaterra, observa ele, a classe desconfia do governo, organiza-se e "se for preciso, revolta-se e luta" (Vianna, 1939). Os partidos que se organizam no mundo anglo-saxão têm fundamento social, e os embates políticos que dele resultam não são choques entre particulares.

Nas circunstâncias específicas da formação nacional, a solução para a organização de interesses viria, segundo Vianna, de sindicatos e conselhos técnicos (Vianna, 1948), verdadeiras escolas políticas que permitiriam o deslocamento do indivíduo de uma condição isolada a outra re- 
lacionada, associada ao vínculo social mais forte e consistente da contemporaneidade: o trabalho, locus de solidariedade social (Vianna, 1948, 1987b). Como observa Werneck Vianna, Vianna admite "a esfera dos interesses como fundamento da organização sócio-política" (1991:176), mas despe-a da premissa liberal do conflito.

Em Populações Meridionais, Vianna sugere que a estrutura social brasileira, calcada na realidade da grande propriedade rural, teria justamente bloqueado a dissonância de opiniões e interesses como fundamento da dinâmica social (Carvalho, 1999). Nas suas obras tardias, Direito do Trabalho e Democracia Social (1948) e Instituições Políticas Brasileiras (1951), ganha forma o argumento de que as organizações de classe podem ser incorporadas à ordem política. Se a política estiver ancorada em classes bem definidas da sociedade, é legítimo que elas pleiteiem ao Estado a realização do seu programa de classe.

A noção de complexos culturais ${ }^{31}$ evoca um fundo ceticismo sobre as possibilidades de os "regimes políticos e constitucionais" modificarem a "alma dos povos" (Vianna, 1987c:67). O clã é evocado como traço permanente de formação da sociedade brasileira ${ }^{32}$. A cultura política engendrada por ele nos distanciaria da experiência inglesa, mas não é necessariamente lida em chave negativa. Sua função simplificadora teria engendrado um "espírito pré-capitalista que bloqueou os conflitos de classe". Não estaríamos fadados, contudo, a uma condição de imobilidade:

Muito ao contrário disso, tudo, em nossa formação histórica como em nossos sentimentos e atitudes tradicionais, nos predispunha e conduzia a esta política de amparo, aproximação e justiça para com os elementos trabalhadores (Vianna, 1987:24).

Aí estariam as bases da transformação possível. Vianna abandona a possibilidade de que o conflito de interesses possa moldar a política do Estado, conforme o modelo anglo-saxão, e reencontra a concepção de política de Torres segundo a qual ela deve ser orgânica e pautada nos princípios de harmonia e equilíbrio de harmonia, de equilíbrio".

No modelo em vista, os diversos grupos organizados apresentam ao Estado suas demandas particulares, não lhes cabendo a elaboração de um ponto de vista que formule uma política geral para a sociedade. Diferente do livre curso dos interesses no contexto liberal, o ambiente imaginado por Vianna prevê o Estado como árbitro que reconhece e 
medeia os interesses de classes subalternas e proprietárias de modo a acomodá-los ao interesse fundamental, raramente evocado no plural: o interesse nacional. A passagem das partes ao todo é operada por um agente externo às disputas potenciais dos interesses imediatos, de órbita estreita. As classes elaboram suas políticas de maneira objetiva, ou seja, tendo por base os seus problemas práticos e interesses, mas a grande política permanece controlada pelo Estado, guiado pelo ideal da harmonia em torno do interesse nacional.

\section{JOSÉ DE ALENCAR, ASSIS BRASIL, GILBERTO AMADO E O ENSAIO DE LIBERALISMO ORGÂNICO}

Nesta seção, tomamos por objeto e recusamos a premissa de identidade estrita entre liberalismo nacional e utopia. Para avançar na hipótese de uma sensibilidade "realista" dos liberais, isto é, de uma preocupação em interpretar a "realidade" e agir sobre ela a partir de estratégias especialmente moduladas para tanto, partimos das obras e discursos políticos de José de Alencar, Assis Brasil e Gilberto Amado. Apesar de absolutamente não integrarem uma única matriz do liberalismo, variando de abordagens mais progressistas até um liberalismo mais conservador, os autores em tela exibem repertórios de interpretação e deontologia para o caso nacional bastante afinados entre si. Entre eles, Amado é sem dúvida o que se acomoda de modo menos evidente na etiqueta liberal operada pelo cânone. Junto a Martins de Almeida, Virgínio Santa Rosa, Caio Prado Júnior e Nestor Duarte, figura na categoria de "intelectuais independentes", de Guerreiro Ramos, "largamente imunes aos vícios típicos do posicionamento hipercorreto" (Ramos, 1983:537). Parece desafiar a fronteira estrita entre sensíveis e insensíveis à realidade nacional. Nós o abordaremos a partir dos três níveis de afinidade com Alencar e Assis Brasil.

O primeiro deles é o suposto comum de que os costumes são objeto potencial de modelagem política, desde que os ensaios de reforma venham calcados em observação acurada das circunstâncias nacionais. Ao arrepio da taxonomia de contrastes, que contrapõe liberais utópicos a intelectuais orgânicos, o conjunto de autores em observação se vincula por laços realistas bem pronunciados. A este respeito notamos a fala de Werneck Vianna sobre Tavares Bastos e endossamos seu conteúdo para tratar dos três pensadores liberais que aqui destacamos:

não há fantasia em Tavares Bastos sobre as condições de implementação do sistema de democracia representativa no país - ele reconhece, 
como seus críticos [Oliveira Vianna], que o terreno lhe é adverso" (Werneck Vianna, 1991:161). Em afinidade com esta proposição, Gilberto Amado, na introdução de Eleição e Representação, endossa cartilha realista que poderia ser creditada aos críticos do liberalismo no país: "abandonai a confusão, o sonho metafórico, ou a exploração das ilusões tolas. Aproximai-vos da objetividade (Amado, 1931:9).

O segundo ponto de aproximação entre os liberais sob investigação é o elogio do proporcionalismo como instrumento de representação da pluralidade de opiniões existentes na sociedade, por princípio superior ao despotismo das massas e à tirania de poucos. Nesta perspectiva, as minorias políticas são pensadas como condição - e não obstáculo - do interesse nacional, distinto por definição dos interesses locais ou particulares que emergem dos sistemas eleitorais de maioria local.

Em terceiro lugar, e em relação estreita com o primeiro e o segundo pontos, convergem em torno do mandato livre como condição de autonomia da representação política. Liberto da tutela dos "interesses tacanhos da localidade", o representante mobiliza sua expertise para construir o interesse nacional, que é o próprio objetivo - e a única base legítima - da representação política. O sistema proporcional com seus distritos amplos fornece a autonomia de ação do representante, ao mesmo tempo que assegura a representação de opiniões existentes na sociedade, ainda que elas existam apenas em estado incipiente.

A identidade pronunciada dos três autores em torno de princípios liberais não constitui um corpo rigorosamente distinto (do ponto de vista de interpretações, princípios e deontologia) de autoritários como Alberto Torres e o próprio Oliveira Vianna. Há entre eles um importante ponto de aproximação: a afinidade em torno do diagnóstico sobre vida social. Grosso modo, compartilham o lamento de um povo apático e desorganizado, aquém das estruturas formais de poder. Ao falar das "massas", José de Alencar atenta para sua condição "perplexa e vaga a respeito das ideias políticas" (Alencar, 1991:67). Para ele, as "turbas" são incapazes. A partir da mesma motivação contrastiva, Gilberto Amado inquieta-se: "Que é o povo brasileiro?". A contragosto, atribui a designação à população restrita de "200 ou 300 mil pessoas" instruídas e dotadas de alguma "noção positiva do mundo". Todo o resto, um agregado amorfo de "caipiras, matutos, jagunços, gaúchos, caboclos, vaqueiros, capangas capoeiras, cangaceiros", e tantos outros tipos sociais desvalidos, são deliberadamente excluídos de 
Realismos Autoritário e Liberal: Aspectos da Imaginação sobre Representação...

sua contabilidade. A conclusão do político poderia vir assinada por Vianna: "não temos corpo eleitoral ativo, democrático, à altura do sistema representativo" (ibidem:47).

A massa de homens que estes pensadores têm sob os olhos sequer faz jus à designação de povo ou sociedade, como Amado deixou claro. Esfacelada em suas partes menores, sem interesses compartilhados que lhe confiram integridade cívica ou política, a "turba" jaz em condição amorfa. O acordo sobre o infortúnio não deprime, contudo, a imaginação social dos autores. Se o estado da arte da população não alimenta a expectativa de um movimento espontâneo e autônomo de superação do caos, tampouco ele revela vícios de índole ou caráter que esterilizem a criação política ${ }^{33}$.

Aqui reside o ponto substantivo de inflexão em relação aos autores do "idealismo orgânico": a crença na possibilidade de aproximar os homens das instituições representativas liberais - sem prejuízo do movimento inverso de aproximação das instituições aos homens. Segundo Amado, todas "as criações espontâneas do meio social resultam, no fundo, do impulso de alguém". Pensando nos partidos - e potencialmente nas instituições representativas liberais em geral - Amado considera que se eles não existem como espinha dorsal da política, podem ser criados pelos "homens bons do país, pelos abnegados, pelos interessados pela coisa pública" com o objetivo de "diferenciar a opinião pública" e alçar o povo de sua condição embrionária (1931:227). As estruturas partidárias evoluirão "naturalmente" para o "aperfeiçoamento", "para a depuração do mal e para a apuração do melhor". Além deste papel os partidos possuem outra função primordial: controlam o Executivo, aspecto que veremos mais adiante.

A despeito de importantes nuances entre si, os autores liberais em vista convergem na imaginação dos meios desejáveis de harmonização entre homens e instituições e, mais especificamente, na crença de que o modelo de representação política deve propiciar a criação dos interesses nacionais que não estão presentes na sociedade brasileira. Ainda sob o impacto da Lei dos Círculos, Alencar deplora que a representação dê vazão à localidade. Quando isto ocorre, "ela decai de sua alta missão; desnacionaliza-se (...). Há uma atrofia política" (Alencar, 1991:58). Para Amado, o sistema distrital uninominal conduz ao parlamento o deputado que, via de regra, serve de voz aos "mandões da aldeia". Ao final deste processo representa-se não o interesse nacional, 
"senão certa soma de interesses confederados no momento, interesses que podem ser apenas a expressão de influências transitórias, alheias, senão hostis aos interesses do país" (Amado, 1931:28) ${ }^{34}$. A representação proporcional seria o meio mais capaz para "ligar, comunicar, entrelaçar todos os fios nervosos da sensibilidade do país nas suas teias infinitas" (ibidem:95). Tal como os autoritários, os liberais colocam no centro das suas preocupações a construção do interesse nacional, entretanto, pensam uma arquitetura constitucional assentada nas instituições liberais representativas.

Entre os recursos que deveriam alterar o padrão das relações atinentes ao mundo político de maneira a aflorar o interesse nacional afinado com as instituições liberais representativas, os mais relevantes, que fazem convergir e divergir os autores sob investigação são: o sistema proporcional, o mandato livre, os partidos políticos e o voto secreto.

O primeiro deles, o proporcionalismo, é o que concentra maiores expectativas de depuração do sistema representativo. Apesar da distância geracional entre os três autores, os termos de adesão à máxima proporcionalista são bastante próximos, bem como as expectativas de renovação cívica e política associadas a ela. Além do repertório positivo de princípios, a validação do sistema proporcional se vale da crítica à "onipotência da maioria" (Alencar, 1991:22), realidade "iníqua e absurda" sobre que repousava então o governo representativo (ibidem:15) ${ }^{35}$.

Neste tópico os autores se aproximam do universo de preocupações do liberalismo europeu do século XIX, com expressão exemplar nas obras de Stuart Mill e Tocqueville. Logo na introdução do seu Sistema Representativo, José de Alencar se situa na cena intelectual da época e reivindica o pioneirismo do seu tratamento da questão da representação das minorias, esclarecendo que suas primeiras publicações sobre a matéria, em 1859, no Jornal do Commercio, antecedem a edição de Sobre o Governo Representativo, do inescapável Mill ${ }^{36}$. Na mesma obra, Alencar também se aproxima inequivocamente de Tocqueville ao endossar o diagnóstico da "tirania da multidão" e seu "odioso despotismo" na realidade norte-americana (Alencar, 1991:14). Próximo ao argumento de Mill em Sobre a Liberdade - este do mesmo ano que seus artigos na grande imprensa da época - define a democracia como "governo de todos por todos", o que implicaria em falsidade - e incorreção científicados regimes que alijam as minorias do processo político. Ainda como 
Mill, Alencar acolhe a premissa de que o debate aprimora as opiniões e qualifica a maioria: "pela resistência ela [a minoria] provocou as inteligências adversas a reagirem, desenvolvendo melhor e apurando suas ideias". A "vontade da pessoa coletiva", afirma, nasce do contato de "pensamentos opostos". Numa arena plural, "a vontade política" que ao final emerge "não pertence ao número superior, mas sim à totalidade" (ibidem:29).

O argumento de Alencar não ignora, entre outros, dois males presentes na sociedade brasileira: o localismo e a ausência de nação. Em linha com sua perspectiva liberal, o antídoto contra eles é a intensificação do caráter democrático da representação, e não, como sugere Santos na interpretação de Vianna e outros "idealistas orgânicos", o desvio autoritário com vistas ao futuro liberal. Um dos traços da originalidade de Alencar reside na sua compreensão de que o governo é democrático não porque exprima a vontade da maioria, fato que o conduziria à tirania da maioria, mas porque representa a diversidade de correntes políticas no país (Santos, 1991: 34-35) ${ }^{37}$.

O argumento de Alencar sobre as minorias é calcado na desconfiança em relação às câmaras unânimes, possivelmente derivadas do alijamento de opiniões relevantes da vida política. Ainda ecoava na imaginação política do autor o receio dos conflitos armados que haviam atormentado o Império e também da interferência, negativa a seus olhos, do poder moderador, dedicado a assegurar a rotatividade entre os partidos e evitar composições eternas de maioria e minorias. Para Alencar, as minorias contribuiriam para a "comunhão de interesses" e para a configuração da política como "expressão comum do pensamento nacional" (Alencar, 1991:176).

Assis Brasil, a respeito da mesma pauta, vai mais longe: as minorias não precisam ser virtuosas; seu papel é o de ser "os cães de fila à porta da caixa pública". Para o autor gaúcho, "com essa fiscalização sem tréguas quem lucra é o país", visto que "o governo, em cujo dorso vibra a incessante aguilhoada de tão austeros fiscais, não terá remédio senão fazer com que, pelo menos, não sejam justas as ferroadas que se lhe aplicarem" (1983:154). Para Amado, as bancadas unânimes sem o contraste das minorias sinalizam a inutilidade do congresso e a ausência de controle do governo ${ }^{38}$. O choque desejado entre visões distintas organizadas em grupos majoritário e minoritários significariam, a um 
só tempo, conflito e controle. Os partidos organizados a partir de ideias distintas tendem a controlar o Executivo.

O sistema proporcional é habilitado, portanto, como garantia desejável de diversificação do processo político. Para tanto, extinguem-se os distritos eleitorais uninominais e, com eles, as bases da política pessoalizada, calcada no "interesse mesquinho" que habilita eleitos como "mandatários exclusivos de certo grupo", e não como "representantes do país, da província ou da cidade". No lugar dos distritos acanhados, o realismo liberal prescreve círculos alargados, do tamanho das províncias, que permitam a representação potencial de homens agrupados em torno de diferentes opiniões e pontos de vista. "Ampliada a área territorial", afirma Alencar, o efeito será "contraditório com o sistema da individuação do voto" (1991:57).

Afeito a esta fórmula, Gilberto Amado opõe a cena que se observa - e não se quer - àquela que não se observa - e se quer. Na primeira, o "voto distrital" e "de simples maioria" é dado "ao indivíduo, ao compadre, ao amigo, ao boss, ao chefe local, ao candidato que pede, insiste, trafica com o eleitor" (1931:70). Na segunda, supera-se o exercício da política como "arte de agradar, de convencer" e afirmam-se as condições do "sistema democrático por excelência", nascido da "distribuição equitativa dos sufrágios ao máximo da sua proporcionalidade" e compatível com uma rotina de "embate das opiniões" (ibidem:99).

Por fim, Assis Brasil se soma à crítica do localismo e à exortação do Congresso como lugar de conflito de ideias, evento que só é possível com o alargamento dos distritos eleitorais. Para ele, os laços de fidelidade entre representantes e representados "conturbam a integridade de espírito" e desviam o representante da tranquilidade necessária ao desempenho de seu ofício. O localismo do voto torna precária - ou mesmo anula - a liberdade política. Em contrapartida, os círculos mais largos, capazes de aglomerar os votos por critérios de afinidade política, fundam a possibilidade de autonomia de juízo da classe política em relação ao interesse público. O entusiasmo com esta ideia levou-o a conceber um único círculo eleitoral para todo o país, embora a apreciação de dificuldades práticas o tenha feito retroceder para a sugestão de unidades eleitorais com a extensão de estados. Nesta nova arquitetura eleitoral, consumada mais tarde pelo Código Eleitoral de 1932, a representação deixaria de ser de conveniências para ser de opiniões ${ }^{39}$. 
Realismos Autoritário e Liberal: Aspectos da Imaginação sobre Representação...

A ativação do processo eleitoral nos seus bons termos vem, em Alencar, associada a uma marcada expectativa de pedagogia política que poderá lançar novas rotinas para a vida pública: ao "disputar a ascendência sobre o povo", os partidos políticos tenderão a "identificá-lo com os interesses permanentes da sociedade", apartando-o dos motivos pessoais como critério de escolha (Alencar, 1991:86). Caso a "plebe" siga reduzida à "condição de pária", ela se "condensará em um só ódio fundo e entranhado contra seu eterno opressor". Na hipótese avessa de lhe permitirem autonomia e representação de ideias, no seu seio se formarão "partidos e antagonismos". Amado converge com este diagnóstico: são os partidos "o único meio de cultura social e política que podemos pôr em prática para elevar as massas brasileiras à compreensão dos destinos nacionais" (1931:197). A inexistência deles favorece a emergência de um presidente que age sem controle e chama para si o papel de portador do interesse nacional. Para evitar tal configuração, os partidos deveriam agir "como um registro, um aparelho regulador, uma bússola, para suprir a opinião de um país sem opinião" (Amado, 1979:138). O favorecimento destas estruturas, "com respeito à sua independência" e "perdão das suas imperfeições", lhes permitirá "exercer sua inconsciente ação educativa através dos esforços contínuos nas lutas quotidianas". A despeito da ambiguidade no tratamento de Alencar e Amado sobre o homem comum - ora descrito como massa desvalida, ora como sujeito dotado de potencial cívico e político -, ele nunca é alijado da representação política.

O desencontro sobre esta matéria específica não chega a configurar dissonância em torno da premissa das funções mediadora e depuradora da representação no processo político. Muito pelo contrário: assim como Alencar, Assis Brasil postula o instituto inescapável da representação, visto que a forma direta da democracia seria "atrasada" e "rudimentar" para lidar com a complexidade da vida moderna. Para Assis Brasil, faltam ao povo "condições para ser órgão direto do governo". Apesar disso, é "fonte do poder". O que há de se aperfeiçoar, portanto, não é o "poder direto do povo, mas a sua capacidade para escolher bons governos" (Assis Brasil, 1983:93). Na imaginação de Alencar, em convergência com a perspectiva de Assis Brasil, a democracia moderna "seria Atenas elegendo e não governando" (Alencar, 1991:59).

Se a distinção necessária entre eleitores e eleitos - descrita por Bernard Manin (1997) como fundamento da representação moderna - carrega marcas elitistas - muito mais pronunciadas em Alencar e Amado que 
em Assis Brasil -, ela não implica em recusa do povo como ator político. Os três autores convergem numa espécie de elitismo não demofóbico que é a marca do seu realismo liberal. Isto é, a habilitação política do povo não parte de imagens românticas sobre ele. Muito pelo contrário: parte do diagnóstico de amorfia e apatia cívica. Dada esta condição - e também uma série de impedimentos de ordem prática - sua inclusão na cena política não poderia prescindir da ação dos "homens superiores", capazes de extrair "da soberania bruta a essência pura" (Alencar, 1991:176). A "virtude e o talento", portanto, devem depurar a vontade popular. O representante não é o espelho de interesses transitórios e limitados expressos na sociedade, a função dele é "sustentar os interesses da comunhão que representa; ser mais do que órgão, ser a razão de um certo núcleo da sociedade" (ibidem:46). Na visão de Amado, o proporcionalismo reafirma o princípio da democracia: "o governo dos mais capazes" (Amado, 1931:72). O representante eleito pelo sufrágio depura os interesses da sociedade, eleva-os e cria o interesse nacional, inexistente numa sociedade amorfa. Ele personifica a expertise e a razão.

Se não é razoável, portanto, estimular a projeção in natura da "plebe" na arena política - e os regimes plebiscitários constituem uma espécie de antimodelo político para Alencar e Assis Brasil -, tampouco há motivos para temê-la: não é ela "inimiga natural das classes abastadas". Movidas por um "pânico sem fundamento", estas classes bem situadas, segundo Alencar, aproveitam-se da sua posição para "extorquir ao pobre o direito do povo e reduzi-lo a uma espécie de servidão política". "Adstritos pela indigência à localidade", não podem, como os ricos, emigrar. Uma vez chamada a participar do governo, a "plebe" se "compenetrará na sua missão" e aprimorará sua condição cívica e política: far-se-á "disposta a ser penetrada pela influência dos homens superiores" (Alencar, 1991:87).

Não há, portanto, em Alencar - bem como em Assis Brasil e Amado um pessimismo sociológico atávico. Menos empenhados na descrição dos vícios do que na busca de meios para superá-los, os liberais em tela atentam para a condição móvel das circunstâncias e convergem numa marcada expectativa de pedagogia da política - ou, mais precisamente, do processo de representação política. Para Alencar, "a genuína democracia, o governo de todos por todos, fará que a plebe, de matéria bruta que é para a revolução, torne-se uma garantia de ordem social". $\mathrm{O}$ voto, os partidos e as eleições, nesta perspectiva, não constituem 
eventos isolados, descolados da sociedade e dirigidos estritamente às arenas parlamentar e política em geral. São concebidos como processo para ativar a transformação de seus operadores, o povo, alçado ao lugar ambíguo de sujeito e objeto da política, a um só tempo.

O otimismo liberal em relação às possibilidades de as instituições ativarem e reformarem positivamente a cena social não vem investido de expectativas mágicas - assim como o olhar para o povo não é romântico. A passagem da condição servil à autônoma não terá um curso breve e tampouco direto. Ele será sinuoso, repleto de hesitações e aberto ao engano. Em aberta exposição de quereres, Assis Brasil (1983) anuncia:

quero que a nação tenha liberdade para fazer os seus maus governos, porque é pelo preço de fazer os maus negócios e de dar os maus passos que os homens e os povos aprendem a dar bons e a ser dignos da sua liberdade.

O exercício político inclui tentativas e erros sucessivos até que os homens alcancem uma situação mais estável e menos suscetíveis à queda (ibidem). Há aqui aproximação com a premissa spenceriana de que o exercício da função aperfeiçoa - ou até mesmo cria - o órgão.

A habilitação política do povo implica numa fórmula delicada entre a assistência dos "mais capazes, talentosos, instruídos e ilustres" e um fazer por si próprio que admite o equívoco, mas deve progressivamente evoluir para o "voto inteligente" (Amado, 1931:30) ou "plenamente consciente" (Alencar, 1991:104). O cidadão qualificado pelo exercício eleitoral aprimora seu voto, mas, importante sublinhar, não chega a prescindir do representante. Refletindo sobre a realidade política dos Estados Unidos, onde "estão a forjar constantemente novas formas de entrelaçamento entre as massas, o povo e o sistema de governo", reconhece que as massas "realizam grandes obras" e chegam mesmo a "purificar as elites e elevar o nível mental dos dirigentes". Entretanto, "não basta ao poder que seja legítimo e emane da soberania popular". É preciso que os negócios públicos e as altas questões de Estado sejam apurados pela "ilustração necessária" (ibidem:175). Amado converge com a ressalva ao apresentar o que é para ele a "essência da democracia": "a escolha por essas massas dos homens mais capazes para dirigir o país" (1931:27). Como observa Tavares sobre Assis Brasil - com aplicação também, a nosso ver, a Gilberto Amado - há uma afinidade pronunciada do autor gaúcho com a premissa schumpeteriana da democracia como sistema pluralista de elites e organizações políticas que 
competem entre si pelo governo. Por meio de eleições periódicas, estes atores obtêm aprovação e delegação da autoridade por cidadãos ordinários, perante os quais são responsáveis (Tavares, 1988:XI-XII). Reconhecendo o caráter elitista do processo político, não abrem mão dos mecanismos competitivos e participativos da democracia liberal.

Dado o protagonismo dos dirigentes, seu mandato é investido de responsabilidade independente. Mesmo considerando a hipótese de um povo reformado pelos costumes, liberto das amarras do localismo e do compadrio, a cena moderna não comporta seu juízo direto sobre as matérias de deliberação política. Cabe aos representantes, conforme Alencar, a "plena liberdade de pensamento na defesa dos interesses que constituíram seu órgão" (1991:66). Para Assis Brasil, diferente do proprietário, "que usa e abusa o objeto de sua propriedade e exerce sobre ele governo absoluto", o "eleitor não exerce governo algum sobre o bem social, que é o objetivo dos cuidados confiados a este" (1983). Nesta perspectiva, a sujeição do representante ao representado em cada uma das suas agendas de deliberação resultaria num círculo demasiado estreito para a ação política. A autonomia de ação do representante é lida, pelos liberais em questão, como condição da vida moderna e constitui mais uma das marcas do seu realismo. Nesta chave, a regra majoritária e o governo direto são descartados como recursos anacrônicos, pertinentes a outras épocas e circunstâncias da política.

Nos tempos que corriam, a política acurada pela ciência revelava a necessidade do "princípio da representação" (Alencar, 1991:11) e do encontro entre "democracia e liberdade" (ibidem:29), mais uma questão clássica do liberalismo inglês do século XIX. Um e outro fundamento exigiam diversificação e disputa de opinião. No modelo liberal que temos em vista, partido e Congresso são os lugares de acolhimento e estímulo da opinião variada, que ultrapassa os limites formais de poder e alcança a sociedade. À diferença dos idealistas orgânicos de Oliveira Vianna, que identificam o Executivo como lugar ou persona de criação da vontade nacional, a teoria da representação política articulada pelos liberais atribui ao Congresso a função de dinamização da vida política. A iniciativa dos mais capazes não exime o povo da necessidade de instrução cívica e política. Esta cena híbrida não pode prescindir de um e outro ator.

\section{NOTAS FINAIS}

A propósito da "mentalidade dos agitadores" republicanos, locutores de uma "política silogística", Oliveira Vianna escreveu o Idealismo da 
Constituição, publicado originalmente em 1924. Na fala do autor, a geração de 1891 figura como expressão-síntese do equívoco republicano original. Alheios à experiência, os criadores do novo regime operariam no vácuo: elegeram "o problema da organização do voto" como "problema capital da nossa democracia" a despeito do fato de não haver aqui "opinião organizada" (Vianna, 1927:11). Inebriados pelo estudo de eventos e personagens além-mar, criaram as bases de um Estado fantasioso, alheio aos fundamentos de sua realidade sociológica.

Os termos da crítica de Vianna ganharam vida longa no pensamento político brasileiro. Além dele, como observamos neste artigo, Guerreiro Ramos e Wanderley Guilherme dos Santos foram autores-chave de um importante cânone interpretativo do campo. Cada um deles prolongou, a seu modo, a linguagem dos contrastes de Vianna, com ajustes conceituais e de interpretação: "assimilativos críticos" e "dogmáticos-dedutivos", no caso de Guerreiro, e "liberais doutrinários" e "autoritários instrumentais", no caso de Santos. Neste artigo, buscamos reunir elementos para superar a rígida dicotomia entre orgânico e utópico, propondo a hipótese do realismo como motivação contínua, e não como ponto de ruptura entre os grupos de intelectuais sob investigação.

Na obra dos chamados idealistas utópicos, como se viu, há inúmeros exercícios de modulação de paradigmas estrangeiros a circunstâncias nacionais, além da habilitação dos homens de Estado como peçaschave da política. Nos escritos de Alberto Torres e Oliveira Vianna, o realismo autoatribuído não descarta a mobilização de instrumentos liberais, como os direitos civis, a participação dos indivíduos via grupos de interesse e um governo com bases legais. Sua crítica era dirigida aos meios de disputa pelo Estado e à ação pública decorrente deles: o conflito entre grupos portadores de opiniões distintas e particulares acerca do Estado gerava um aparelho público aparentemente subordinado ao interesse comum, mas, na prática, instrumento de grupos vencedores que implementavam sua agenda política. Tal crítica possuía um sentido amplo, direcionada a sociedades ditas modernas e também àquelas que aspiravam modernidade. Trata-se de um conjunto de valores destoante dos liberais aqui evocados, afeitos ao conflito como dinâmica da política.

José de Alencar, Assis Brasil e Gilberto Amado nunca negligenciaram as condições pouco propícias à instalação do modelo liberal no país e lançaram-se à imaginação de modos de captura da sociedade pela polí- 
tica - com vistas ao possível movimento futuro e inverso de captura da política pela sociedade. A crença nos instrumentos liberais como meios de transformação da "plebe" não implica em inconsciência a respeito de sua condição escassamente política e cívica. O próprio comedimento dos liberais no uso dos conceitos "povo" ou "sociedade" - que supõem condições mínimas de organização e unidade do corpo de representados - e a mobilização mais corriqueira das noções de "plebe", "massas" ou "multidões" é elucidativa dos diagnósticos de fragmentação social e distância da nossa sociologia em relação àquelas das nações que gestaram o liberalismo. Foi justamente a sensibilidade ao cenário social disponível que motivou os três autores em questão, cada um a seu modo, a elaborar ferramentas institucionais capazes de se contrapor à sociologia esfacelada, capturá-la e reelaborá-la. A inspiração e a alegação realistas são pronunciadas na sua obra.

Se acolhemos a premissa de que tanto autoritários como liberais são orientados por diagnósticos de circunstância, o interesse passa a ser o de investigar diferentes modos de realismo - e seus respectivos desdobramentos normativos. Diferente desta orientação, a linguagem dos contrastes de Vianna, Ramos e Santos parte da premissa do realismo como recurso objetivo e escasso, distribuído desigualmente entre grupos de intelectuais.

Para Ramos, o irrealismo das ideias enunciadas pelos liberais utópicos teria como contraface um marcado e imediato realismo de interesses. A adesão à bandeira federalista, por exemplo, visaria atender aos interesses das oligarquias dominantes nas províncias (Ramos, 1966:347). Sua intervenção na cena pública seria orientada, portanto, por um viés particularista, confinado aos interesses de grupos específicos da sociedade e alheio ao interesse nacional. Por contraste, caberia aos "críticos assimilativos" a "superioridade da razão", "malgré a inobjetividade de teoria do processo" (ibidem:361). Em última instância, contudo, o processo histórico possuiria um telos inequívoco, o desenvolvimento nacional, e este possuiria uma política: aquela preconizada exclusivamente pelos críticos assimilativos, apesar de suas limitações. A leitura de Santos sobre os liberais utópicos aproxima-se da visão de Ramos sobre a mesma matéria. A despeito de importantes nuances e distinções interpretativas, convergem no diagnóstico de autismo político dos liberais.

No lugar da polaridade presença-ausência, abordamos o tema do realismo a partir de duas importantes modulações: uma operada por 
Realismos Autoritário e Liberal: Aspectos da Imaginação sobre Representação...

autoritários e outra por liberais. Nos dois modelos de representação política a dissonância realista manifesta-se em um pequeno conjunto de tópicos normativos que não colidem com os dois níveis basilares de acordo e convergência já referidos: a sensibilidade às circunstâncias específicas do país e a ênfase na ação criadora do Estado, operador do interesse comum.

Discordamos, portanto, de Gildo Marçal Brandão, quando afirma que

tanto quanto os idealistas orgânicos o idealismo constitucional dos liberais afirma a centralidade do papel do Estado na formação social brasileira, com a radical diferença de que para os primeiros é o caráter inorgânico da sociedade que põe a necessidade de um Estado forte que a tutele e agregue, ao passo que para os segundos, é a presença do Estado todo-poderoso que sufoca a sociedade e a fragmenta (2007:48).

Se a crítica liberal de um "Estado todo-poderoso" é de fato procedente, dela não deriva a recusa em geral do Estado - mas de certa configuração dele, viciosa. Também para os liberais que temos em vista o diagnóstico de uma sociedade desorganizada motiva a imaginação de um Estado iniciador do processo político e também social. Se esse movimento não prescindirá da sociedade, tampouco está inteiramente legado às suas mãos.

As distinções significativas em relação à matriz do idealismo orgânico de Vianna concentram-se na definição de instrumentos e meios de ação do Estado. Para os liberais que temos em vista, a habilitação política de minorias de opinião por meio do mecanismo da representação proporcional constitui o caminho por excelência para superar a condição de amorfia cívica. A conversão das massas ou turbas em povo, investida de sentido de unidade, é operada por uma delicada engenharia política e eleitoral que prevê, por meio do sistema representativo, mediação e depuração das ações dos homens comuns, contra quem não devem se abater as rotinas de fraude. O povo é, a um só tempo, origem e destino da política.

No argumento autoritário, por oposição, a construção do interesse nacional requer primordialmente a exclusão da diversidade de opiniões que compõem - real ou virtualmente - a sociedade nacional. Nesta perspectiva, interesse nacional e pluralidade de opiniões caminham em sentidos opostos. Do conflito ou choque de perspectivas não resultará a unidade que se quer para o interesse. A distância entre as famí- 
lias intelectuais em tela escapa, portanto, ao contraponto entre utopia e realismo, e se funda nas bases sempre móveis e nada objetivas dos argumentos que buscam validação no real e em modelos de representação política.

(Recebido para publicação em abril de 2015)

(Reapresentado em outubro de 2015)

(Aprovado para publicação em abril de 2016) 
Realismos Autoritário e Liberal: Aspectos da Imaginação sobre Representação...

\section{NOTAS}

1. Ver Azevedo (1996), publicado originalmente em 1943.

2. Ver Menezes (1950).

3. De autoria de ambos: "As Ciências Sociais no Brasil". Série Estudos e Ensaios, no 6, Capes.

4. Ver Fernandes (1956, 1957, 1958a e 1958b).

5. Acompanhamos aqui o elenco de "autores-fonte" apontado por Wanderley Guilherme dos Santos e também o diagnóstico de um corte institucionalista operado por eles (à exceção única de Guerreiro Ramos) em artigo com levantamento sistemático sobre o campo do pensamento social e político brasileiro (Santos, 1967).

6. Referência ao argumento da "viagem redonda" de Raymundo Faoro em Os Donos do Poder: Formação do Patronato Político Brasileiro, publicado originalmente em 1958. Perspectiva reforçada em Faoro (1994).

7. Vale notar, por exemplo, que o Código Eleitoral de 1932, assinado por Assis Brasil, traduziu em forma de lei as diretrizes principais de sua obra sobre a matéria, Democracia Representativa: Do Voto e da Maneira de Votar, publicada originalmente em $1892 \mathrm{e}$ consideravelmente revisada na edição de mesmo ano do código (com introdução do voto feminino). O referido texto lança as bases fundamentais do sistema eleitoral nos seus termos contemporâneos.

8. A exceção inescapável aqui é Rui Barbosa. Como se sabe, ele foi o principal autor do texto da primeira Carta Republicana e objeto das graves acusações de utopismo de Oliveira Vianna. O leitor familiarizado com o período poderá estranhar sua ausência no elenco de autores liberais que compõem este artigo. Cabe o esclarecimento de que o político e pensador baiano nunca dedicou reflexão sistemática ao tema da representação política, tendo esboçado comentários a respeito em dois momentos tópicos: a Campanha Civilista de 1909, na qual concorreu pela Presidência da República com Hermes da Fonseca, e a Campanha da Bahia de 1919, quando, já no fim da vida, acompanhou candidato à sucessão política local em excursão eleitoral. De todo modo, nos fragmentos de discurso sobre a matéria, sua digressão escapa aos termos de uma perspectiva liberal clássica, de cujo mimetismo é acusado. Na altura da Campanha Civilista, Rui Barbosa manifesta incômodo com o princípio do conflito como dinâmica fundamental da política e acolhe com entusiasmo o tema da unidade nacional objeto, aliás, de desacordo acirrado com Assis Brasil, manifesto em convenção civilista de 3 de outubro de 1909 (Barbosa, 1909:80). Para ver mais sobre o assunto, consultar o capítulo 3 de Hollanda (2009). Para uma recuperação da reflexão política de Rui Barbosa, veja-se Lamounier (1999).

9. Gildo Marçal Brandão toca marginalmente este tema quando adota, não casualmente, o conceito "idealismo constitucional", no lugar de "utópico", do mesmo Oliveira Vianna. Segundo ele: "a categoria-chave da estratégia liberal é a da 'construção institucional', historicamente cumulativa. Não cabe, por isso mesmo, aceitar a priori o adjetivo utópico que Oliveira Vianna pespega como sinônimo de constitucional" (Brandão, 2007:50).

10. Sobre esta incapacidade, veja-se especialmente Vianna (1987c, cap. VII) e Carvalho (2002). 
11. Recuperamos o termo usado por Wanderley Guilherme dos Santos no seu clássico ensaio "Paradigma e História: A Ordem Burguesa na Imaginação Social Brasileira" (1978).

12. Sobre as ênfases distintas destes valores ao longo da sua trajetória, veja-se Carvalho (1999 e 2002) e Werneck Vianna (1999).

13. Guerreiro Ramos $(1954,1995,1961,1966$ e 1983). A trajetória intelectual de Guerreiro Ramos foi analisada por diversos trabalhos. Em relação ao tema específico deste artigo, destacamos Oliveira (1995). O empenho de Guerreiro Ramos em mapear autores do pensamento social e político brasileiro não pode ser inteiramente separado da polêmica com Florestan Fernandes sobre critérios da produção científica, conforme referido na introdução deste artigo. Em razão de seus espaços e enfoque, contudo, não retornaremos ao tema.

14. Consideramos que o texto de 1966 representa a sua maior elaboração sobre o tema.

15. Veja-se também Guerreiro Ramos (1966:360-361).

16. A distinção de carácteres entre "pragmáticos críticos" e "hipercorretos" abre uma importante brecha para a crítica a Guerreiro: por que motivo, afinal, os primeiros são isentos de "ação interessada"? Não são escassas as evidências de vinculação entre locutores do programa centralizador e os interesses do grupo cafeicultor situado no norte fluminense, dos setores crescentes da burocracia estatal nos anos 1930 ou ainda dos grupos industriais beneficiados pela proteção ao mercado interno ao longo das décadas de 1950 e 1960. Ver Lenharo (1993).

17. Em "O Problema do Negro na Sociedade Brasileira", originalmente publicado em 1955, este movimento é bastante evidente. Neste artigo, o principal termo de juízo da reflexão sobre raça é a vocação nacional ou não dos autores, o que o leva, por exemplo, a "desculpar" a antropologia racista de Vianna: "mesmo errando ao focalizar o tema da raça soube vencer a tentação de tratar o negro no Brasil como um elemento exótico e petrificado. Tratou-o como brasileiro" (Ramos, 1981:50). Por outro lado, Nina Rodrigues, Arthur Ramos e Gilberto Freyre e, entre os "mais recentes", Florestan Fernandes e Thales de Azevedo, "beatos da ciência importada" (ibidem:52), são acusados de operadores de uma "ideologia de brancura ou de claridade", bastiões de um pensamento "alienado".

18. Para um apanhado sistemático sobre a fase inicial da obra de Wanderley Guilherme dos Santos (1963-1978), ver Lynch (2013).

19. Os "outros" enxergam o autoritarismo como permanência (e não instrumento provisório), articulando justificações de ordem naturalista (caso de Plínio Salgado e dos integralistas) ou histórica (caso de Francisco Campos e, sobretudo, Azevedo Amaral).

20. A tal tradição aderiram, por exemplo, João Quartim de Moraes (1993), Élide Rugai Bastos (1993) e Francisco Weffort (2006).

21. Entre outros autores dedicados à crítica do princípio de autoritarismo instrumental, Ricardo Silva a articula de maneira sistemática atribuindo a Santos uma compilação enviesada de fragmentos esparsos da obra de Oliveira Vianna (Silva, 2004). Seu argumento se organiza em dois eixos. No primeiro deles, Silva discorda da suposição de transitoriedade associada à premissa instrumental, uma vez que a noção de sociedade liberal evocada por Santos poderia remeter a uma sociedade estritamente de mercado, cujos fundamentos, como se sabe, em nada colidem com o recurso autoritário. Silva nota que Santos mobiliza conceitos vários do campo semântico do liberalismo 
de modo intercambiável com o conceito de democracia, embora a premissa da equivalência seja de todo equivocada. Quanto ao segundo eixo, em articulação com o primeiro, ainda que se pudesse admitir a equiparação entre liberalismo e democracia, caberia uma questão fundamental: que democracia? A resposta necessariamente apontará na direção de uma democracia corporativa, que se realiza sem eleições e sem eleitores e, dado o diagnóstico de amorfia cívica do povo, sem democracia direta. Sua positividade estaria no agenciamento de competências técnicas que substituem a competência parlamentar.

22. Outro viés da crítica apresentada é a "premissa de objetividade do real", imputada também a Guerreiro Ramos, conforme visto há pouco. Junto com Santos, seriam as figuras-chave da matriz historicista-nacionalista do autoritarismo.

23. Segundo Santos, Lamounier não esclarece se, no outro lado do espectro político, haveria ideologias políticas isentas de noções de Estado. Por vezes parece caminhar neste sentido, o que "contraria de Karl Polanyi e Laski a C. B. Macpherson e de Locke a Marx" (Santos, 1978:32). Em outros momentos, parece acolher na hipótese do modelo de mercado a noção normativa de Estado. Nestes casos, seu conceito "nada diferencia" e é de todo estéril (ibidem:33).

24. Além da confusão conceitual, Lamounier concorda com concepção determinista quando concebe a ideologia de Estado como "espelho fiel da sociedade e dos conflitos através dos quais é transformada". Segundo Santos, "se não se trata de uma banalidade, mas de uma afirmação epistemológica sistemática, então é curioso que Lamounier não tenha percebido que uma das dimensões de sua crítica à suposta ideologia do Estado, no Brasil, aplica-se inteiramente à posição epistemológica, sua" (Santos, 1978:33).

25. Trata-se de visão distinta daquela não raro mobilizada por autores do Pensamento Social Brasileiro, que enxergam na Teoria Social elaborada no Brasil elementos de novidade derivados de sua perspectiva e condição periférica. Um exemplo desta abordagem pode ser encontrado em Maia (2009, especialmente entre as páginas 157 e 161).

26. Vieira Pinto operaria o mesmo equívoco com as categorias "consciência ingênua" e "consciência crítica" (Santos, 1966:88).

27. Deixaremos de lado, por fugir ao escopo do artigo, importante bibliografia sobre Torres que se concentra, por exemplo, nos temas da reforma política, da miscigenação e da transplantação de instituições exógenas à formação nacional. Entre outros autores e obras que tratam destes tópicos estão Kuntz (2002), Lombardi (2010) e Marson (1979).

28. Alberto Torres elabora um complexo modelo de representação política calcado na imaginação do Poder Coordenador como protagonista da harmonia social. A peculiaridade desse poder residiria em seu caráter vitalício, um importante anteparo em relação à ordem republicana flutuante ao sabor dos humores. O Poder Coordenador seria constituído por um Conselho Nacional com o número máximo de 20 membros vitalícios designados pelas duas Casas do Congresso e pelo Supremo Tribunal. Somente por força de sentença judicial poderiam estes homens perder o cargo. Quanto à questão representativa, Torres propunha uma alteração na composição dos órgãos legislativos. Segundo o modelo proposto, metade da Câmara seria eleita pelos distritos eleitorais, um quarto pelos estados e outro um quarto por todo o país. Quanto ao 
Senado, cinco senadores seriam eleitos por todo o país, 21 nomeados pelos estados e 35 seriam produto de representação de classes, sendo 8 indicados pelo clero católico e demais instituições de caráter religioso, 3 indicados por associações e academias literárias e científicas, 2 pelos magistrados e advogados, 2 pelos médicos, farmacêuticos e cirurgiões-dentistas, 2 pelos engenheiros industriais, 5 pelos lavradores que cultivassem produtos de exportação, 6 pelos lavradores e produtores em geral de gêneros de consumo no país, 4 pelos operários urbanos e agrícolas, 2 pelos banqueiros, comerciantes, corretores e pessoas que exercessem profissões congêneres, e pelos funcionários civis e militares, e 1 pelos jornalistas (Torres, 1982:307-315). A fragmentação do eleitorado em categorias profissionais, e até em subcategorias profissionais, teria menos a função especular da representação e mais o intuito de incentivo à gestação e consolidação de interesses sociais.

29. Sobre as etapas da reflexão de Oliveira Vianna veja-se Brasil Jr. (2007); Carvalho (1999 e 2002) e Werneck Vianna (1991).

30. Ao comentar as campanhas eleitorais e, em particular, a campanha de 1910 de Rui Barbosa, Oliveira Vianna aponta sua influência benéfica sobre os eleitores, notadamente, aqueles que se encontram sob a tradicional mentalidade de clã. Sua ação benéfica não será imediata, mas o contato destes homens do mundo rural com ideias, programas, compromissos e planos de governo lhes permitirá, pouco a pouco, alcançar uma vida moral mais alta e mais digna do que aquela vivida em torno ao chefe clânico. Além do benefício aos eleitores, esse contato também permitiria aos candidatos tomar conhecimento direto e experimental dos interesses das regiões percorridas. Veja-se Vianna (1974:107).

31. “Os complexos culturais formam um sistema articulado onde vemos objetos ou fatos de ordem material, associados a reflexos condicionados, com os correspondentes sentimentos e ideias" (Vianna, 1987c:63). Uma análise da ideia de complexo cultural na obra de Oliveira Vianna pode ser encontrada em Brasil Jr. (2007).

32. “Quanto ao espírito de clã que é o mal que envenena a nossa existência - não creio que possamos mover contra ele uma política de eliminação completa, de expurgo integral, que nos permita colocar nosso povo em paridade com o povo inglês. (...) Creio, porém, que nos será possível sempre realizar, neste sentido, uma política de neutralização, tanto quanto possível dos espíritos de clã na nossa vida pública" (Vianna, 1987b:129).

33. Entre os três autores sob investigação, Assis Brasil foi o menos eloquente na referência ao povo desorganizado. Tal como José de Alencar e Gilberto Amado, partiu do diagnóstico social negativo, mas - ainda com os dois, embora de forma mais pronunciada - escapou ao postulado de uma negatividade essencial. Sendo "filhos das circunstâncias", os homens são feitos de matéria maleável, passível de ajuste. Nos idos da República, a condição não desejável dos homens devia-se, sobretudo, à rotina das relações políticas, personalistas, avessas por princípio ao interesse público. Seus ensaios de reforma - que alcançaram principal expressão no Código Eleitoral de 1932, de sua autoria - se organizaram em torno do objetivo de moralização das cenas eleitoral e política, com ecos inescapáveis na vida social. Os vícios não configuram, nesta perspectiva, obstáculo à transformação.

34. Ver também Amado (1931:44-46). 
35. Santos (1991:29-30 e 49-50) aponta cinco pontos da originalidade de Alencar frente aos seus contemporâneos, notadamente Stuart Mill e Tocqueville: a) a defesa da densidade do mandato; $b$ ) a vinculação entre proporcionalidade da representação e qualidade da democracia; c) recusa dos costumes de tirania da maioria e veto da minoria e d) a associação entre tempo curto de mandato e prática democrática.

36. Sobre este aspecto veja-se Santos (1991). Para uma abordagem distinta de Santos, veja-se Rizzo (2012).

37. É digno de nota que Santos ao recuperar e propor a reflexão sobre Alencar como um clássico do pensamento político brasileiro não faça menção às categorias do autoritarismo instrumental ou do liberalismo doutrinário.

38. Ver os discursos de 12/9/1925 e 3 e 7/12/1922 publicados em Amado (1979:165 e 135).

39. Entre os antídotos ao localismo e ao personalismo na política, a obra de Alencar apresenta, como recurso complementar à fórmula proporcional, a defesa entusiasmada da eleição em dois turnos. Para ele, a forma indireta do voto era condição para a "nacionalização da representação", com "depuração das fezes locais" (Alencar, 1991:130). Ao cercear a proximidade física entre eleitor e representante feria-se o "espírito de provincialismo" e as práticas do "bairrismo funesto" (ibidem:132). Além do objetivo estritamente eleitoral - de equacionamento entre votos e mandatos - os dois turnos fixavam na representação uma função mediadora do processo político. Na época moderna, afinal, os homens ocupavam-se de sua individualidade e sobrava-lhe pouco para conceder à vida pública. O protagonismo cívico combinou-se nela à complexificação da política, que "adquiriu fóros de ciência" e se fez "inacessível às turbas" (ibidem:36). Entre a política e o povo interpunham-se agora a falta de tempo e a incapacidade. Para suprir esta lacuna, Alencar evoca os "superiores talentos" (ibidem:39). O tema da incapacidade do homem comum, que afina Alencar com o argumento conservador da época, não inibe, contudo, sua habilitação ao processo político. Muito pelo contrário: a inclusão das "turbas" no processo eleitoral é condição de legitimidade da representação política - e por isso o político tece forte crítica ao critério censitário como princípio de exclusão eleitoral. No seu modelo não é possível prescindir delas, mas habilitá-las num regime plebiscitário, sem instrumentos de depuração da vontade, seria temerário. Chamadas a participar da cena pública na medida de sua capacidade, elas devem apenas manifestar confiança em figuras de prestígio local e são eximidas das funções de maior complexidade. Os representantes que resultarem do segundo turno das votações ocuparão em relação a elas - as "turbas" - o lugar de "pais e tutores" que não poderão ser "revogados a seu arbítrio", do mesmo modo que filhos não podem, conforme o direito civil, renunciar aos pais (ibidem:114). Esta inclusão política por via não política - a confiança - não configura, entretanto, uma cena necessária, fadada à reprodução indefinida. 


\section{REFERÊNCIAS BIBLIOGRÁFICAS}

ALENCAR, José de. (1991) [1868], “Sistema Representativo”, in W. G. dos Santos, Dois Escritos Democráticos de José de Alencar. Rio de Janeiro, UFRJ Editora, pp. 3-205.

AMADO, Gilberto. (1931), Eleição e Representação. Rio de Janeiro, Ophicina Industrial Graphica.

. (1979), “O Funcionamento do Legislativo (7-12-1922)”, in H. Senna (org.), Perfis Parlamentares. Brasília, Câmara dos Deputados, pp. 131-139.

ASSIS BRASIL, Joaquim Francisco de. (1983) [1896], A Democracia Representativa na República (Antologia). Seleção e introdução de Vicente Barreto. Brasília, Câmara dos Deputados, Coordenação de Publicações.

AZEVEDO, Fernando de. (1996), A Cultura Brasileira: Introdução ao Estudo da Cultura no Brasil. Brasília, Editora UnB; Rio de Janeiro, UFRJ Editora.

BARBOSA, Rui. (1909), Obras Completas de Rui Barbosa - Excursão Eleitoral, vol. XXXVI, tomo 1.

BASTOS, Élide Rugai. (1993), “Oliveira Vianna e a Sociologia no Brasil”, in E. R. Bastos;

J. Q. Moraes (orgs.), O Pensamento de Oliveira Vianna. São Paulo, Unicamp, pp. 405-425.

BERNARDES, Denis A. de Mendonça. (2006), O Patriotismo Constitucional? Pernambuco, 1820-1822. São Paulo/Recife, Hucitec.

BRANDÃO, Gildo Marçal. (2007), Linhagens do Pensamento Político Brasileiro. São Paulo, Aderaldo \& Rothschild Editores.

BRASIL JR., Antonio. (2007), Uma Sociologia Brasileira da Ação Coletiva: O Debate entre Oliveira Vianna e Evaristo de Moraes Filho. Dissertação (Mestrado em Sociologia), Universidade Federal do Rio de Janeiro, Rio de Janeiro.

CARVALHO, José Murilo de. (1999), “A Utopia de Oliveira Vianna”, in Pontos e Bordados. Belo Horizonte, UFMG Editora, pp. 202-231.

. (2002), Introdução a Populações Meridionais do Brasil. Intérpretes do Brasil. Rio de Janeiro, Nova Aguilar, vol. I.

CARVALHO, Maria Alice Rezende de. (1998), O Quinto Século: André Rebouças e a Construção do Brasil. Rio de Janeiro, Revan/Iuperj.

COSTA PINTO, Luiz de Aguiar; CARNEIRO, Edison. (1955), "As Ciências Sociais no Brasil". Série Estudos e Ensaios, 6, Capes.

FAORO, Raymundo. (1994), Existe um Pensamento Político Brasileiro? São Paulo, Ática. . (2001), Os Donos do Poder: Formação do Patronato Político Brasileiro. Rio de Janeiro, Globo.

FERNANDES, Florestan. (1956), “Ciência e Sociedade na Evolução Social do Brasil”. Revista Brasileira, ㄲo 6 .

. (1957), "Desenvolvimento Histórico-Social da Sociologia no Brasil". Anhembi, vol. XXV, no 74, ano VII, pp. 470-481. 
Realismos Autoritário e Liberal: Aspectos da Imaginação sobre Representação...

. (1958a), O Padrão de Trabalho Científico dos Sociólogos Brasileiros. Belo Horizonte, UFMG (Coleção Estudos Sociais e Políticos).

. (1958b), A Etnologia e a Sociologia no Brasil. São Paulo, Anhembi.

FERREIRA, Gabriela Nunes. (1999), Centralização e Descentralização no Império: O Debate entre Tavares Bastos e Visconde de Uruguai. São Paulo, Editora 34/Departamento de Ciência Política da USP.

HOLLANDA, Cristina Buarque de. (2009), Modos da Representação Política: O Experimento da Primeira República Brasileira. Belo Horizonte, UFMG Editora.

. (2011), Joaquim Francisco de Assis Brasil: Uma Antologia Política. Rio de Janeiro, Editora 7 Letras.

KUNTZ, Rolf. (2002), “A Organização Nacional”, in L. D. Mota (org.), Introdução ao Brasil: Um Banquete nos Trópicos. São Paulo, Editora Senac, pp. 261-278, vol. 2.

LAMOUNIER, Bolívar. (1985), “Formação de um Pensamento Autoritário na Primeira República", in B. Fausto (org.), História Geral da Civilização Brasileira, Tomo III, vol. II. São Paulo, Difel.

. (1999), Rui Barbosa e a Construção Institucional da Democracia Brasileira. Rio de Janeiro, Nova Fronteira/Fundação Casa de Rui Barbosa.

LENHARO, Alcir. (1993), As Tropas da Moderação. Rio de Janeiro, Secretaria Municipal de Cultura e Turismo.

LOMBARDI, Maria Fernanda. (2010), “O Pensamento Político de Alberto Torres: A Reforma Constitucional e o Estado Brasileiro", in G. N. Ferreira; A. Botelho (orgs.), Revisão do Pensamento Conservador. São Paulo, Editora Hucitec/Fapesp, pp. 95-118.

LYNCH, Christian Edward Cyril. (2013), “The Institutionalization of Brazilian Political Thought in the Social Sciences: Wanderley Guilherme dos Santos' Research Revisited (1963-1978)". Brazilian Political Science Review, vol. 7, no 3, pp. 36-60.

MAIA, João Marcelo. (2009), "Pensamento Brasileiro e Teoria Social: Notas para uma Agenda de Pesquisa". Revista Brasileira de Ciências Sociais, vol. 24, no 71, pp. 155-168.

MANIN, Bernard. (1997), The Principles of Representative Government. Cambridge, Cambridge University Press.

MARSON, Adalberto. (1979), A Ideologia Nacionalista de Alberto Torres. São Paulo, Duas Cidades.

MENEZES, Djacir. (1950), "La Science Politique au Brésil au Cours des Trente Dernières Années", in La Science Politique Contemporaine. Paris, Unesco, pp. 237-241.

MORAES, João Quartim. (1993), “Oliveira Vianna e a Democratização pelo Alto”, in E. R. Bastos; J. Q. Moraes (orgs.), O Pensamento de Oliveira Vianna. São Paulo, Unicamp, pp. 87-130.

OLIVEIRA, Lúcia Lippi. (1995), Sociologia do Guerreiro. Rio de Janeiro, UFRJ Editora.

RAMOS, Alberto Guerreiro. (1954), “O Tema da Transplantação e as Enteléquias na Interpretação Sociológica no Brasil". Revista do Serviço Social, ano XIV, no 74, pp. 72-95.

(1961), A Crise do Poder no Brasil. Rio de Janeiro, Zahar. 


\section{Cristina Buarque de Hollanda e Ivo Coser}

. (1966), “O Formalismo, no Brasil, como Estratégia para Mudança Social”, in Administração e Estratégia do Desenvolvimento. Rio de Janeiro, FGV Editora, pp. 331-422.

. (1983), “A Inteligência Brasileira na Década de 1930 à Luz da Perspectiva de 1980", in A Revolução de 30 - Seminário Internacional. Brasília, Editora UnB, pp. 527-548.

. (1995) [1957], Introdução Crítica à Sociologia Brasileira. Rio de Janeiro, UFRJ Editora.

1981 [1955], “O Problema do Negro na Sociologia Brasileira”, in S. Schwartzman (org.), O Pensamento Nacionalista e os "Cadernos do Nosso Tempo". Brasília, UnB, Câmara dos Deputados, pp. 39-69.

REGO, Walquiria G. Domingues Leão. (2002), A Utopia Federalista. Estudo sobre o Pensamento Político de Tavares Bastos. Maceió, Edufal.

RIZZO, Ricardo. (2012), Sobre Rochedos Movediços: Deliberação e Hierarquia no Pensamento Político de José de Alencar. São Paulo, Hucitec.

SANTOS, Wanderley Guilherme dos. (1996), "Preliminares de uma Controvérsia Metodológica". Revista Civilização Brasileira, nos 5-6, pp. 77-94.

. (1967), “A Imaginação Político-Social Brasileira". DADOS - Revista de Ciências Sociais, nos 2/3, pp. 182-193.

. (1970), “Raízes da Imaginação Política Brasileira”. DADOS - Revista de Ciências Sociais, no 7, pp. 137-161.

. (1978), “Paradigma e História: A Ordem Burguesa na Imaginação Social Brasileira. A Práxis Liberal no Brasil: Propostas para a Reflexão e Pesquisa", in Ordem Burguesa e Liberalismo Político. São Paulo, Duas Cidades, pp. 15-63.

. (1991), “Introdução”, in Dois Escritos Democráticos de José de Alencar. Rio de Janeiro, UFRJ Editora, pp. 9-56.

SILVA, Ricardo. (2004), A Ideologia do Estado Autoritário no Brasil. Chapecó, Argos.

SOBRINHO, Barbosa Lima. (1968), Presença de Alberto Torres. Rio de Janeiro, Civilização Brasileira.

TAVARES, José Antonio Giusti. (1988), “A Teoria da Representação Política e do Governo em Assis Brasil”, in J. A. Brasil, A Democracia Representativa na República (Antologia). Brasília, Conselho Editorial do Senado Federal, pp. IV-LXXIII.

TORRES, Alberto. (1982), Organização Nacional. São Paulo, Editora Nacional/Brasília, UnB Editora.

VIANNA, Francisco José de Oliveira. (1939) [1927], O Idealismo da Constituição. São Paulo, Companhia Editora Nacional.

(1948), Direito do Trabalho e Democracia Social. Rio de Janeiro, Livraria José Olympio.

. (1974) [1930], Problemas de Política Objetiva. Rio de Janeiro, Record/Editora UFF.

. (1981) [1924], “O Idealismo da Constituição”, in V. L. Cardoso (org.), À Margem da História da República. Brasília, UnB Editora.

. (1987a) [1958], Introdução à História Social da Economia Pré-Capitalista no Brasil. Belo Horizonte/Rio de Janeiro, Ed. Itatiaia/UFF. 
Realismos Autoritário e Liberal: Aspectos da Imaginação sobre Representação...

. (1987b) [1949], Instituições Políticas Brasileiras. Itatiaia, Editora da USP / Rio de Janeiro, Eduff. Vol. I.

. (1987c), Instituições Políticas Brasileiras. Itatiaia, Editora da USP/Rio de Janeiro, Eduff. Vol. II.

. (1987d) [1920], Populações Meridionais do Brasil. Itatiaia, Editora da USP / Rio de Janeiro, Eduff. Vol. I.

WEFFORT, Francisco. (2006), Formação do Pensamento Político Brasileiro. São Paulo, Ática.

WERNECK VIANNA, Luiz. (1991), “Americanistas e Iberistas: A Polêmica de Oliveira Vianna e Tavares Bastos". DADOS - Revista de Ciências Sociais, vol. 34, no 2, pp. 145-189.

. (1999), Liberalismo e Sindicato no Brasil. Belo Horizonte, UFMG Editora. 


\section{RESUMO}

Realismos Autoritário e Liberal: Aspectos da Imaginação sobre Representação Politica em Fins do Século XIX e Princípios do XX

O artigo explora a premissa de contraste estrito entre "idealistas utópicos" e "orgânicos" suposta por autores que, a despeito de importantes diferenças analíticas e geracionais, se alinham num dos mais destacados cânones do pensamento político brasileiro: Oliveira Vianna, Guerreiro Ramos e Wanderley Guilherme dos Santos. No lugar do rígido dualismo, sugerimos importantes afinidades entre os ditos utópicos e orgânicos. Atentos ao tema da representação política, abordaremos os dois universos intelectuais em questão a partir das obras dos liberais José de Alencar, Assis Brasil e Gilberto Amado, de um lado, e dos autoritários Alberto Torres e Oliveira Vianna, de outro. A nosso ver, os dois grupos de autores convergem no diagnóstico sobre a condição sociológica nacional (clânica e parental) e também na sua imaginação de futuro (afinada com as expectativas de unidade nacional e iniciativa política do Estado). $\mathrm{O}$ contraste inequívoco entre os grupos reside sobretudo nos diferentes atores e estratégias de ativação estatal: entre os liberais, o parlamento opera conflito desejável entre as partes que disputam concepções de interesse público; entre os autoritários, a razão de Estado é própria de um sujeito cognoscente privilegiado, o governante, a quem cabe imprimir unidade às cenas social e política.

Palavras-chave: autoritarismo instrumental; liberalismo brasileiro; Primeira República; Oliveira Vianna; Assis Brasil

\section{ABSTRACT \\ Authoritarian and Liberal Realisms: Features of the Imagination on Political Representation at the Turn of the Twentieth Century}

This article explores the premise of a strict contrast between "utopian" and "organic idealists" among authors who, despite significant analytical and generational differences, are aligned along one of the most prominent canons of Brazilian political thought: Oliveira Vianna, Guerreiro Ramos and Wanderley Guilherme dos Santos. Instead of a rigid dualism, we suggest important affinities between the utopian and organic strands. Sensitive to the subject of political representation, we approach the two intellectual universes in question based on the works of liberals José de Alencar, Assis Brasil and Gilberto Amado, on the one hand, and the authoritarian Alberto Torres and Oliveira Vianna, on the other. In our opinion, the two groups of authors overlap in their diagnosis of the national sociological condition (both clan-like and parental) and also in their imagination of the future (in tune with the 
expectations of national unity and the State's political leadership). The unwarranted contrast between the groups is fundamentally based on the different actors and strategies for state involvement: among liberals, parliament fosters a desirable conflict between parties disputing matters of public interest; while among authoritarians, the State's role is that of a privileged cognoscente, in the form of the governor, whose role it is to imprint unity on the social and political scenes.

Key words: instrumental authoritarianism; Brazilian liberalism; First Republic; Oliveira Vianna; Assis Brasil

\section{RÉSUMÉ}

Réalismes Autoritaire et Libéral: Aspects de l'Imaginaire sur la Représentation Politique au Tournant du XXème Siècle

Cet article explore la prémisse de contraste strict entre "idéalistes utopiques" et "organiques" supposée par des auteurs qui, en dépit d'importantes différences analytiques et générationnelles, s'accordent sur l'un des canons les plus représentatifs de la pensée politique brésilienne: Oliveira Vianna, Guerreiro Ramos et Wanderley Guilherme dos Santos. En lieu et place de ce dualisme rigide, nous suggérons d'importantes affinités entre les utopiques et les organiques. En portant une attention particulière au thème de la représentation politique, nous aborderons les deux univers intellectuels en question à partir, d'un côté, des œuvres des libéraux José de Alencar, Assis Brasil et Gilberto Amado, et de l'autre, des autoritaires Alberto Torres et Oliveira Vianna. De notre point de vue, les deux groupes d'auteurs convergent quant au diagnostic sur la condition sociologique nationale (clanique et familiale), mais également ce qui concerne leur vision du futur (liée aux expectatives d'unité nationale et d'initiative politique de l'État). Le contraste sans équivoque entre les groupes réside surtout dans les différents acteurs et stratégies de la mise en œuvre de la politique d'État : pour les libéraux, le Parlement génèrerait un conflit sain entre les parties se disputant diverses conceptions de l'intérêt public, tandis que chez les autoritaires, la raison d'État est propre à un sujet éclairé et privilégié, le gouvernant, à qui il revient de faire régner l'unité sur les scènes sociale et politique.

Mots-clés: autoritarisme instrumental; libéralisme brésilien; Première République; Oliveira Vianna; Assis Brasil 


\section{RESUMEN}

Realismos Autoritario y Liberal: Aspectos de la Imaginación sobre Representación Política a finales del Siglo XIX y principios del Siglo XX

El artículo explora la premisa de contraste estricto entre "idealistas utópicos" y "orgánicos" supuesta por autores que, a pesar de importantes diferencias analíticas y generacionales, se alinean en uno de los más destacados cánones del pensamiento político brasileño: Oliveira Vianna, Guerreiro Ramos y Wanderley Guilherme dos Santos. En lugar del dualismo rígido, sugerimos importantes afinidades entre los mencionados utópicos y orgánicos. Atentos al tema de la representación política, abordaremos los dos universos intelectuales en cuestión a partir de las obras de los liberales José de Alencar, Assis Brasil y Gilberto Amado, por un lado, y de los autoritarios Alberto Torres y Oliveira Vianna por otro. A nuestro parecer, los dos grupos de autores convergen en el diagnóstico sobre la condición sociológica nacional (de clanes y parental) y también en su imaginación a futuro (afinada con las expectativas de unidad nacional e iniciativa política del Estado). El contraste inequívoco entre los grupos reside sobretodo en los diferentes actores y estrategias de activación estatal: entre los liberales, el parlamento opera un conflicto deseable entre las partes que cuestionan concepciones de interés público; entre los autoritarios, la razón de Estado es propia de un sujeto cognoscente privilegiado, el gobernante, a quien cabe unificar las escenas social y política.

Palabras clave: autoritarismo instrumental; liberalismo brasileño; Primera República; Oliveira Vianna; Assis Brasil 